Social and Economic Impact Analysis of Vadinar Refinery of Essar Oil: The Case of a Mega Refinery

Sumana Chaudhuri, Shovan Ray

Indira Gandhi Institute of Development Research, Mumbai April 2016

http://www.igidr.ac.in/pdf/publication/WP-2016-011.pdf 


\title{
Social and Economic Impact Analysis of Vadinar Refinery of Essar Oil: The Case of a Mega Refinery
}

\author{
Sumana Chaudhuri ,Shovan Ray \\ Indira Gandhi Institute of Development Research (IGIDR) \\ General Arun Kumar Vaidya Marg \\ Goregaon (E), Mumbai- 400065, INDIA \\ Email(corresponding author): shovan@igidr.ac.in
}

\begin{abstract}
The paper is a case study of Vadinar refinery in Gujarat. It examines the costs and benefits associated with one of the world's mega refinery projects highlighting the welfare impacts on society. The paper briefly examines whether refining at Vadinar by Essar is of net economic benefit to the region, state and the country by constructing a Social Cost Benefit Analysis of the Vadinar Refinery Project. The paper analyses the local-level economic impacts (on-site labor impacts, local revenue and supply chain impacts and induced impacts) and jobs supported by Vadinar refinery construction and ongoing operations. The paper also analyses the regional (state and country) level economic impacts; multiplier effect of income, tax and savings generated as a result of the refinery operations, including other externalities associated with the project. There is abundance of scope to reflect the strategic food and oil security of India from the macroeconomic perspective; the gradual increase in investor and consumer confidence with respect to self-reliance in production and consumption of oil and natural gas resources in the country and the broader social impact of the project, which may be taken up in subsequent research. A sequel to this paper will explore an approach to integrating the methods with a CGE model framework.
\end{abstract}

Keywords: Social Cost Benefit Analysis, Economic Impact, Externalities, Oil Refinery

JEL Code: B41, D60, D61, D62, H23, H43, L71,O22, Q43 


\title{
Social and Economic Impact Analysis of Vadinar Refinery of Essar Oil: The Case of a Mega Refinery
}

\author{
Sumana Chaudhuri \\ Assistant Professor, Durgadevi Saraf Institute of Management Studies, Mumbai \\ and \\ Shovan Ray \\ Professor, Indira Gandhi Institute of Development Research \\ Mumbai
}

\begin{abstract}
The paper is a case study of Vadinar refinery in Gujarat. It examines the costs and benefits associated with one of the world's mega refinery projects highlighting the welfare impacts on society. The paper briefly examines whether refining at Vadinar by Essar is of net economic benefit to the region, state and the country by constructing a Social Cost Benefit Analysis of the Vadinar Refinery Project. The paper analyses the local-level economic impacts (on-site labor impacts, local revenue and supply chain impacts and induced impacts) and jobs supported by Vadinar refinery construction and ongoing operations. The paper also analyses the regional (state and country) level economic impacts; multiplier effect of income, tax and savings generated as a result of the refinery operations, including other externalities associated with the project. There is abundance of scope to reflect the strategic food and oil security of India from the macroeconomic perspective; the gradual increase in investor and consumer confidence with respect to self-reliance in production and consumption of oil and natural gas resources in the country and the broader social impact of the project, which may be taken up in subsequent research. A sequel to this paper will explore an approach to integrating the methods with a CGE model framework.
\end{abstract}

Keywords: Social Cost Benefit Analysis, Economic Impact, Externalities, Oil Refinery

JEL Code: B41, D60, D61, D62, H23, H43, L71,O22, Q43 


\subsection{Introduction}

Petroleum, Oil and Lubricants (POL) commands a strategic and critical role in the growth and development of nations. These constitute a major part of energy used in India's economy, second only to coal as source of primary energy, and can spur growth in most sectors. India has been traditionally a net importer of POL products. The country is being forced to spend valuable foreign exchange to procure additional energy resources. In the recent past, there has been a growing concern to boost production of petroleum and natural gas from domestic sources as well as hydrocarbons equity abroad. At present India imports nearly three-fourths of its crude requirements. Investing in domestic oil and natural gas exploration is a long-term solution that will help quench India's growing energy demands. Since oil and natural gas also play a critical role in deciding the inflation rate, the rising prices for these energy commodities have long been a point of contention in Indian politics. After Government of India allowed private participation in petroleum refining in India, Essar Oil set up a 9 MMTPA oil refinery at Vadinar in Gujarat, which started commercial production on May 1, 2008. The current capacity of the refinery now stands at 20 MMTPA. With state-of-the-art technology, it has the capability to produce petrol and diesel that meets the latest Euro IV and Euro V emission standards. The refinery produces LPG, Naphtha, light diesel oil, Aviation Turbine Fuel (ATF) and kerosene. It has been designed to handle a diverse range of crude - from sweet to sour and light to heavy. It is supported by an end-to-end infrastructure setup, including SBM (Single Buoy Mooring), crude oil tanker facility, water intake facilities, a captive power plant, product jetty and dispatch facilities by both rail and road. To date, Essar Oil's Vadinar refinery has successfully processed more than 75 varieties of crude from across the world, including some of the "toughest crudes". This comes with an increase in its complexity from 6.1 to 11.8 on the Nelson index, making it India's second largest single-location refinery and amongst the most complex globally.

In this study, the researchers propose to conduct a preliminary study on social costbenefit analysis (SCBA) for the Vadinar refinery using up-to-date information to estimate the costs and benefits associated with the project. The purpose of the study is to briefly examine whether the commercial refinery project at Vadinar is socially beneficial overall for the refinery business. The economics of a refinery are complex and depend on many factors. Profits or losses result primarily from the difference between the cost of inputs and the price of outputs. In the oil refining business, the cost of inputs (crude oil) and the price of outputs (refined products) are 
both highly volatile, influenced by global, regional, and local supply and demand changes. The question of whether the business of refining in aggregate is socially desirable and economically beneficial is adequate to justify the aggregate cost of running the refinery. The analysis is done in stages as the effects of a mega-refinery, in fact any refinery, are wide-ranging as they spill over not just in their local area of activity but much beyond, extending to the national economy and polity. It is intended that this complex process is captured in some meaningful way with a very high degree of professional norms. There are however certain effects which may not be amenable to these standards, but we wish to give pointers to these directions in what follows.

A mega-project like the Vadinar Oil Refinery has wide-ranging external consequences to the economy and society, and this needs to be assessed for India in the larger political economic context which has major implications for concerns and consequences at the highest policy circles. This is done in what follows. Some of these effects and follow up measures, howsoever important they might be, may not be amenable to measureable techniques. They are nevertheless important to note for their strategic fallout. Major policy changes were to follow and these are captured in what follows this macroeconomic policy discussion. In the next section, we present a brief summary of the construction and commissioning of the Vadinar refinery that is targeted to capture the design features and concerns of these policy changes. Once the refinery is constructed and the refinery commissioned, huge changes are brought about in the ecosystem of that region, and some of these local features are captured in the section that follows. It may be noted that these are all part of the external benefits that are associated with the setting up of the refinery which make a splash in the region, and thus feed into the calculation of SCBA, which follow as the centrepiece of this study.

\subsection{Organization of the Article}

This article is structured as follows. After the introduction, the second section focuses on the background of the study, with the macro externalities of the petroleum refineries as a universal intermediary, followed by a detailed review of the hydrocarbon sector in India. Section three covers the scope of the study with the description and design of the EOL's Vadinar Refinery for the period under consideration, followed by Socioeconomic and Development Externalities are discussed in the fourth section. The fifth section deals with the review of extant literature in Cost Benefit Analysis (CBA). CBA of the Vadinar Oil Refinery Project, taking into account the externalities, is analysed in the sixth section. The limitations of the study are discussed in the 
seventh section, followed by a brief summary and scope for future work in the concluding section.

\subsection{The climate of shortage and imbalance}

\subsection{The Macro externalities of petroleum refineries}

The hydrocarbons sector of Indian economy has seen considerable growth for several decades alongside increased income of its citizens and growth in the national economy. The nature of this growth has many aspects, and it is useful to highlight them at the outset. Hydrocarbons form a major part of the total energy sector in India, and with growth in the economy it is a natural process that energy demand increases, and at a rate determined by the character and parameters of the energy intensity of growth. If economic growth is energyintensive it follows that all subsectors of energy would feel the pressure of demand growth. However, some subsectors may outpace others, at rates determined by the economic structure. We see that the Indian economy has not only experienced high energy demand, but also a considerable shift in demand for hydrocarbons in general and specific petroleum products (such as diesel and other middle distillates) in particular.

There are two dimensions to this growth profile of energy demand. Oil and natural gas have not only direct use in specific sectors like transport (motor spirits, diesel, CNG, in households, industry, etc.) they are also used, very significantly, as 'universal intermediates'. Thus petroleum products are not only used in transporting vehicles and firing gas stoves in households, the products of this industry are used as inputs in a variety of activities in a manner that can be best described as 'universal intermediates'. Thus natural gas can be used in power plants as much as coal as inputs, which in turn power several activities in the economy. Similarly, gas, naphtha and other products of this sector can be used for fertilizers, along with other multiple uses, and fertilizers are used as inputs in agriculture. Naphtha and other products can be cracked to derive ethylene, propylene and others, and these in turn can be used as inputs for producing mono- and poly-products such as polypropylene, with multiple uses in garments, packaging, plastics, food and several other uses. It is not just that the products of this industry (oil) are used in specific sectors like transport, but also assume a more pervading character. Its ramifications are huge and thus its security and stability to the economy is enormous. With growth in the Indian economy in the sustained manner that has been recorded for several decades now, it is natural that there is almost an insatiable demand for the hydrocarbons sector 
and its various derived products. This has been perceived in policy circles for some time and has helped in its development in recent decades.

Speaking about the character of the growth process underway, some specific issues such as the character and speed of urbanization are also important to underline, since this has been considerable in India. This growth in urban economy is true of all emerging economies in the world, and included those of the newly industrialized world in Asia and other continents. With urbanization comes not only considerable growth in urban transport that is frequently noted, but also other demands made by urban dwellers in procuring supplies from elsewhere in the country. Thus a variety of industrial products arrive from other cities and industrial centres, but also agricultural products ranging from common cereals, to fruits and vegetables and dairy products, grown in the countryside. Hence there is enormous demand on transportation to move products to urban centres; there is also in turn the increasing demand arising from agriculture on fertilizers, pesticides and other products of industry to produce increasing supplies to these centres; and these increase non-linearly in view of increasing incomes of the urban middle classes. It is these issues that must be kept abreast in appreciating the enormous pressures on the petroleum sector to fuel the growth in the economy. What happened in the course of the decades would be easier to comprehend then.

An important point generally missed in the context of inflationary process can be captured in this context. A balanced and stable production of petroleum products is paramount in this process of controlled target of inflation. When we measure inflation impacts through metrics like the wholesale and retail price indices (WPI and CPI) in the economy, it is not simply the weights of crude and petroleum products in the weighting diagrams of the indices being considered. Through their universal character, these products enter into consumption and production of most other sectors and add to inflationary pressures through secondary and tertiary effects. Prices of agriculture could rise, for instance, as a result of its impact, and so could their transportations to centres of consumption, and also through fertilizer prices reflected on producer prices. If these prices are not contained, then the subsidy burden to the exchequer of the large weight of food and fertilizer subsidies spiral, as we have seen in recent decades; these in turn add to the fiscal deficit burden and hence on the inflationary pressures. Inflation management is a huge social responsibility of any incumbent government and this in no small measure is better served by a responsible growth and stability of the hydrocarbons sector.

India's food security through rapid strides in the agriculture sector in the last few decades is well documented. It started in the late 1960s and gathered pace in the 1970s and 1980s, and sustained with some attendant costs since then. However, it had some distinct characters as it 
spread its wings. It was orchestrated through the Green Revolution, which had several features: it was mainly through increase in yields per acre; it was confined to the principals cereals, rice and wheat, and later extended to certain crops like maize and sugarcane and others in select areas; it was confined first to the Indo-Gangetic plains of India and then spread to coastal peninsular India. For increasing crop yields, common features were the new technology and seeds that depended on controlled water supply (irrigation), fertilizers and power, all of which were copiously supplied with heavy subsidy elements built into them. Petroleum products have made an important contribution in achieving and sustaining that. India's much debated green revolution leading to food security would have been a pale shadow of its success without generous dozes of subsidized inputs, in all of which hydrocarbons have played important roles, be they irrigation (diesel generated pump sets), fertilizers and pesticides, tractors, power tillers, harvesters, etc. Food security apart the income generated in the regions and prosperity of farmers was enormous.

A few other macroeconomic and social effects of the enormous importance of the oil sector may be quickly listed. India has been deficient in crude petroleum and products in relation to its net demand for several decades. As a result, there have been large deficits in the external trade account for imports of crude oil for refining and products for direct consumption to meet this burgeoning demand. Consequently, the deficit on the foreign exchange account was ballooning and the external value of the rupee was traditionally under pressure in a controlled exchange regime. As a result the rupee was considered to be overvalued. This was to a large extent contributed by the ballooning deficit in the demand supply gap of this sector, and this was considered serious till such time that the economy was liberalised in the early years of 1990s. In fact the critical phase leading to the crisis in the economy in the 1990s and opening up of the economy soon after and two successive devaluations of the rupee (in 1991) was in no small measure the reflection of this scenario. With liberalisation and globalisation of the Indian economy many changes have been wrought, including the controlled regime in the petroleum sector, the new exploration licensing policy for oil sector (NELP) and the administered pricing mechanism (APM) that was to be replaced. It is important to note here that the management of the exchange rate in a controlled regime gives rise to a shadow exchange rate that may be different from the actual prevailing rate, and thus management of the oil sector is a task of considerable policy significance. Increased production of crude oil and refinery products thus add considerably to the benefits accrued to the economy at the national scale.

There is also pricing and supply chains for petrochemicals as downstream products of refineries. These influence the growth and locations of downstream products around the 
country. For instance, economies around the world with large refining sectors, whether they are located in the Middle East, Southeast Asia (Singapore), or the United States, petrochemicals industries have grown in tandem with the growth of refineries, and these add considerable value chains in the economy with their boosts to output, employment and taxes in the economy. This has happened in India too with the development of the refining sector located in different parts of the country. Today the supply of petrochemicals products is so plentiful that even in rural India with masses of low income households, they have made pervasive inroads. Even in poor villages and hamlets, a visitor is offered a plastic chairs which they can afford rather than natural woven materials where they were made to squat. Several decades back, natural cotton was the apparel of the masses as they could not afford the synthetics. Today the synthetics fabrics are the apparel of the masses even in rural areas as they have replaced the natural fibres like cotton, which have become items of luxury at home, and for exports to markets abroad.

A parallel example may be drawn from automobiles and its linkages with autoancillaries, both growing in lockstep. There are strong case histories of these linkages from around the world where production takes place; these case histories may be cited from the United States, Britain, Germany, Japan, and recently from China, South Korea and India. Going a step backward, the Steel industry has very strong downstream linkages, including the just cited examples of automobiles and ancillaries. In fact Japan built its giant steel industry even without the local availability of iron ore; and China's huge steel capacity is sustained largely by imported ore from India, Australia and several other locations; a similar example is South Korea, and all these three East Asian economies were dependent on imported ores in varying proportions. All these industries form a chain of metals-based sector. The story is similar for refineries and their products, which are petrochemicals. The first is Ferrous-metal-based value chain, and the refinery chain, whether built on local or imported crude, provide the petrochemicals value chain. Both these groups, when established provide enormous potential for value addition, employment and income generation, and direct and indirect tax collections. This underlines the independent standing of refineries as an engine of growth even when domestic sourcing of crude oil is limited; when domestic prospecting and production is added, the chain gets even stronger.

The pricing of petroleum products in the market is another instrument of social policy, quite apart from the downstream products and pricing of petrochemicals industries discussed above. It has been noted earlier that these products as universal intermediates, unless properly managed, have inflationary consequences. There is also social policy of direct subsidy to consumers in various forms such as kerosene (SKO) subsidy, LPG subsidy and till recently administered pricing mechanism of motor spirits and diesel. Increase in these prices (or even 
their full-cost pricing) can make significant holes in budgets of the poor and the middle classes, and hence they are sensitive to social and political order in India. It is not just that income levels matter (through transfers policy of product pricing), which they do, but inequality among social classes may have consequences on social order. While attempts have been made for several decades to contain the scale and target beneficiaries of petroleum subsidies, mainly in the household and agricultural sectors, the magnitudes continue to be large in scale and inefficient in terms of leakages. These are sensitive issues and government policies are always alert on them in a democratic set-up.

While in a study of the social costs and benefits of a large refinery it would be important to capture the 'shadow price' of good social order and its stability consequences on the investment climate for business prosperity, it may be an elusive animal to chase. Nevertheless, it is worth keeping in mind the importance of social order. It is after all what makes a lot of difference to the intangible elements that define business confidence. A volatile climate may not be conducive to the 'animal spirits' of entrepreneurs. Hence, even if this study is unable to measure this element of enormous benefits to the economy and society, the 'peace dividend' may be considered significant.

\subsection{The Hydrocarbons Sector}

The oil industry is closely monitored by the Government of India in view of the factors mentioned above; the industry has come a long way through various stages of reforms since independence, when the prevailing regime set pricing of international oil companies benchmarked at import parity prices of landed petroleum products. In very broad brush strokes, the industry has passed through nationalisation of oil companies, and the Oil Pricing Committee (OPC in 1976) of Government of India set prices of refinery products at 'retention prices'. The retention price benchmarked product prices at technical efficiency norms for procuring all major refinery products from a wide range of refineries located in dispersed centres, with a wide array of technologies and vintages for producing the output. Clearly a shelf of technologies of different vintages refined with different grades of crude procured from different sources and at different locations are very different cost centres These refined products procured at their designated retention prices were pooled in an oil pool account and marketed by the main marketing companies through a formula of equated prices at different locations in India. This process resulted in subsidies to consumers and cross-subsidies among different products marketed at administered prices set by the Government. For instance, kerosene (SKO) which was widely used by the poor and many sections of households in rural areas, for cooking and lighting was highly subsidised. By contrast, aviation turbine fuel (ATF), both of which came 
from the same light end of the distillation column of the refinery, was used in air transport and used mostly by the affluent. Clearly, the resultant cost recoveries by the oil companies were very different. All subsidies to designated consumers and cross-subsidies among product categories were pooled in a prescribed manner and taken by the oil marketing companies on their books. The Ministry of Oil and Natural Gas absorbed the net budgetary subsidies that were the outcome and financed them through budget provisions of the Government of India.

This is a very compressed account of a very complex process of crude oil being procured from different sources and put through different refineries located in India to produce a variety of petroleum products and distributed to consumers for final consumption or further processing for different products. In addition, a large share of the refinery products were imported as the total domestic availability was far short of the emerging demand by product consumers at household, agriculture, industry and services sectors. The landed costs of these products also figured as part of the final costs on which marketing margins were added. The Oil Pool Account and the Oil Coordination Committee (OCC) under the Ministry of Petroleum and Natural Gas of Government of India had a major task on hand to manage this gigantic machinery, and lubricating it was not a simple matter of accounting and economic reasoning. Economic efficiency, development priorities and social and political considerations were all involved in setting pricing and distribution parameters. This came under huge strain as the economy expanded, shortages ballooned and deficits on account of subsidies escalated. The need for domestic and foreign investments from sources other than government in the hydrocarbons sectors became an urgent imperative.

When trade accounts are in deficit due to burgeoning import demands (both crude and products), it is important both to increase domestic supply and investments from abroad. They meet two ends. First, the shortage is reduced (both crude and products) and thus trade deficit is narrowed as imports are scaled down. Secondly, foreign investments into the sector ease the situation enormously by acting on the second front, that is the capital account in the balance of payments. The current account deficit that may remain is sought to be bridged through capital flows in general, and especially so if they flow into the sector that directly augment domestic supplies. This was indeed the situation that prevailed in the 1990s, the setting when domestic and foreign equity investments were sought both for oil exploration in India (and oil equity abroad) and for investments in refineries. The dramatis personae included Essar Oil Limited and Reliance Industries, both major domestic investors and who were to set up giant refineries in Jamnagar, Gujarat. 
The Technical Group (TG) set up by the Ministry (MoPNG) in 1996 following the reforms proposed by the ' $\mathrm{R}$ ' Group listed the main objectives of reforms in the hydrocarbons sector: a) to promote efficiency in the Oil and Natural Gas Sector: Downstream and Upstream; b) to provide a rational framework for new investments in the oil sector; and c) to create an environment wherein consumers can buy petroleum products at competitive prices. The TG noted that petroleum products consumption during 1995-96 was 72.5 MMT with a demand growth of more than 7\% per annum and expected to be 112 MMT by the end of IX plan period and grow to 149 MMT by 2010. It noted that the capability of India's oil sector to meet the growing oil demand "is extremely critical for sustaining the growth of the economy. India will remain a net importer of crude oil and petroleum products in foreseeable future." To achieve its strategic objectives to acquire capability to match supply imbalances, "the order of magnitudes of investments required in oil and gas sector projects even on a conservative system could be anywhere between 100-150 billion US Dollars which will have to be ploughed during the next 10-12 years. It has been estimated that total investment required in Hydro Carbon sector during the IX Five Year period would be to the tune of approximately Rs.1, 24,000 crores.

"To compliment the efforts of PSUs in building the infrastructure required to meet the projected demand, it is equally necessary to invite private capital. Investor would be reluctant to commit large funds in the petroleum sector in a regulatory regime ... Hence there is an urgent need to initiate a viable economic policy package which would accelerate the reform process and chalk out a critical path with strategic milestones." The Technical Group noted inter alia "that huge investment is planned ... in the Hydro Carbon sector but a firm commitment for a major portion of these funds was yet to take place." This was noted at a time when the Essar Oil Group had already received the LoI from the Foreign Investment Promotion Board (FIPB) in 1992 and was constructing the Vadinar Refinery in Jamnagar. But its plans had been hit by a massive cyclone on 9 June 1998 that devastated its site.

\subsection{Vadinar Refinery of Essar Oil Limited: Description and Design}

Essar Refinery was built by Essar Projects from a Greenfield area, which was a large piece of barren land and EPIL developed all allied units, associated utilities and captive power plant with addition of several units to produce higher grades of fuels. In spite of a number of unfortunate delays due to natural calamities like severe cyclone in 1998, massive earthquake in 2001, required environmental clearances, the first phase of 10.5 MMTPA of the project was successfully commissioned by November 2006 and commercial production started in May 2008. Refinery 
Train 1 expansion was commissioned in March 2012 and then augmented and achieved 20 MMTPA refinery capacity. Some highlights of the project are discussed below.

On receiving the approval from Government of India in December 1992, Essar Group commissioned Foster Wheeler Energy Limited (FWEL) of UK in 1993 to prepare the Detailed Project Report for the proposed 9.0 MMTPA capacity refinery. FWEL assessed that by 1998-99, "the two refineries planned by Reliance and Essar, each with 9.0 MMTPA capacity, are expected to be operating with full capacity. Similarly, the three Government owned refineries of HPG, BPC and IOC, each with a capacity of 6.0 MMTPA, are expected to be fully operative by year 2003-04. These five planned refineries would thus add 36.0 MMTPA, increasing the total refining capacity in the country to 108.55 MMTPA (Product availability: 100.75 MMTPA). Even at this increased level of crude throughput, the growing demand would necessitate product imports in all the future years. Assuming all the approved and planned additions to the refining capacities, totalling to about 57 MMTPA, materialise in the next 10 years, there would still be a need to import about 12 MMTPA in the year 2003-04.

"Another factor which needs consideration is the impact of world demand on product prices. If the demand increases in any region of the world, product prices are likely to shoot up; resulting in further outgo of critical foreign exchange for countries like India; importing substantial quantities of petroleum products. In addition, refinery margins will increase to provide the necessary investment to satisfy increasing product demand elsewhere in the world. It is thus advantageous to build additional refining capacity in the country to minimise dependence on imports of products. This situation augurs well for addition of refining capacities at current cost of investment, and the timing of execution of this project by Essar Group in India is considered appropriate." Its assessment of demand situation for Middle Distillates was summed up thus: "There would be shortage of 11 to 26 MMTPA of middle distillates in case A (without Essar). Even after Essar and the other refineries come on stream, a shortage of 2 to 7 MMTPA would continue." This was an assessment for the engineering design of the Greenfield refinery at Vadinar. The consultants also considered the demand situation in the region and found scope for exports of surplus lines of products. "The scope for exports to this deficit region [of Asia] by Indian Refineries thus exists. Essentially, the deficits would comprise middle distillates and unleaded gasoline. It will, therefore, be advantageous for the new refineries coming in India to plan their refinery configurations keeping these options in mind. Essar's refinery configuration has been designed to take this into account."

"The project facilities have been selected taking into consideration the various parameters relating to crude availability, product demand, product specifications, and crude and product 
pricing patterns. Consideration has also been given to likely future changes in Refinery operation with respect to pricing mechanism in the domestic oil industry and effect of stringent environmental regulations on product specifications."

Refinery Design: There was a clear perception of engineering design to take advantage of evolving market dynamics: "The objective will be to make high value middle distillate products which would be in shortage. The market will thus absorb all the middle distillates produced in this Refinery. The objective will also be to produce the additional high value product, Unleaded Motor Gasoline (87 RON), for which certain shortfall exists. While, the Refinery will be designed to cater to this domestic market, should the need arise sufficient flexibility is kept in the processing facilities for exporting high value Mogas/Reformate over and above what can be absorbed in the domestic market. In case, a surplus naphtha situation arises the same would be exported directly and/or could be converted into Mogas with export specifications.... there is a good scope for exporting light and middle distillates to the South East Asian markets. The facilities provided will enable the refinery to convert Naphtha to Mogas / Reformate and export if need arises. A Kerosene Hydrotreater and Gas Oil Hydrodesulphuriser could be installed at a later date, if low sulphur Kerosene and HSD also need to be exported. The objective will be to convert the heavier cuts (fuel oil material) into high value products like middle distillates and Mogas as stated above. With this approach the fuel oil production will be minimised to the extent economically possible. LPG is also another high value product in demand and facilities will be incorporated for maximum recovery of LPG produced from the Crude Distillation unit and that generated by the secondary conversion units like Fluid Catalytic Cracker and the Hydrocracker." Thus refinery specifications were meticulously targeted to the market situation. Environmental standards and regulatory parameters, as also energy conservation protocols, were specified and built into the design.

Project Cost and Financing Plan: The project would cost Rs. 5544 crore including 25\% import duty on imported components of plant and machinery, with Foreign Exchange component of Rs.1124 crore and Rupee component of 4420 crore. The project would be financed under a financial package with the Debt-Equity Ratio of 0.98: 1. The details of these costs and their financing plan are available in the DPR for the refinery. The report observed: "The financing plan may undergo changes as the project develops. However, this will not have a material effect on calculations."

Financial Analysis as per DPR: Each refinery receives a return on investment which is based on the company's net worth. On the net worth portion, the company receives a post- tax return at $12 \%$ and on the borrowings the rate of return equals the weighted average interest rate paid by 
the company during the base year. These principles and provisions have been used in the determination of retention price for the financial projections of the Essar refinery project. On the basis of accepted parameters and norms, the following highlights emerged. The Internal Rate of Return (IRR) was $20.38 \%$ on pre-tax basis, and post-tax IRR was $17.25 \%$. Average Return on Equity (ROE) was $52.82 \%$ over the project period. Average Return on Investment (ROI) on PBDT basis was $23.01 \%$. Simple Payback Period was 49 months. The proposed project was considered as very worthwhile financially, quite apart from its economic contributions and the strategic interests that it served.

Construction and Commissioning: When the Essar Refinery was conceived in 1993 and its detailed project report prepared for 9 million ton crude throughput capacity, the cost was estimated at Rs.5544 crores at current prices and at Rs.33 per US dollar. The first phase of 10.5 MMTPA of the project was successfully commissioned by November 2006 and commercial production started in May 2008 and then followed by a massive cyclone. Refinery Train 1 Expansion was commissioned in Mar 2012 and then augmented and achieved 20 MMTPA Refinery capacity. Together with captive power generation for the refinery and other utilities dedicated for the project, the Vadinar refinery of EOL cost them roughly Rs.40,000 crores at current prices and exchange rates. In terms of size, capacity and costs, the project is a massive enterprise; as a Greenfield project in a barren part of the Saurashtra region of Gujarat, it would make a major difference to the local and regional landscape, and attract many enterprises and allied activities like a magnet. The effects would be huge; in what follows an attempt is made to assess its neighbourhood consequences, especially with regard to socioeconomic aspects. The national level consequences will be captured as well. This massive project has significant international ripple effects too, which are treated as leakages for this study and will not be identified.

ABB Lummus Crest was appointed the Project Management Consultants for the 10.5 MMTPA Oil Refinery at Vadinar, India. ABB's responsibilities included Engineering, Procurement, Construction Supervision, Pre-commissioning and Commissioning of this major project. They came in November 1995 to Vadinar site with expats team \& also recruited locally from Jamnagar \& Vadinar. Essar Projects team started shifting in 1995 \& entire mobilization for the Refinery was completed by the year 1996 through internal transfers, new recruitments including locals, outsiders \& expats.

In this project three phases were ascribed the following percentage weights as per ABB Lummus Global norms for this Project: i) Engineering 15\%; ii) Procurement 35\%; and iii) Construction $50 \%$. Once the basic engineering phase had been completed, ABB Lummus moved to the 
detailed engineering phase. To do this a contracting plan was identified, and they appointed four nominated engineering sub-contractors (NESs). The NESs were responsible for the detailed engineering (amongst other supervisory responsibilities). The detailed engineering management were vested with the following four NESs: a) ABB LCM; b) Engineers India Limited (EIL) ; c) Tata Consulting Engineers (TCE) ; and d) Howe India Projects Limited (HIPL).

To conjure up what materialised over the construction phase of 1993 to 2007 for 10.5 MMTPA base refinery, the following account gives an outline: Scope of work included Procurement, Complete Construction, erection, testing \& commissioning for all units of base Refinery along with the associated utilities. The following were deployed:

Peak Labour Force 12,000 nos.

Concrete - 3,20,000 cubic meter

Structural steel - 24,000 Metric Ton

Tanks \& Spheres - 5900 Ton

Heaters - 5000 Ton

Underground Piping - 33,00,000 Inch Meter

Glass Reinforced Piping - 34,00,000 Inch Meter

Above Ground Piping - 72,00,000 Inch Meter

Equipment - 2600 Ton

Heavy Lift -7 nos.

Electrical Cabling - $2200 \mathrm{KM}$

Instrumentation Cabling - $1700 \mathrm{~km}$

Insulation - 3,22,00,000 cubic meter

Painting $-17,25,000$ sqr. Mtr.

Building - 54 nos.

After the cyclone, however, the whole dynamics of the project changed.

Phase 2001-2003: After cyclone, works suspended at Refinery site during this phase. During that period discussions happened between Essar, ABB Lummus and Financial Institutions on environmental clearances issues.

Phase 2003-2004: Since the project was held up for a long time, during the restart in May-2005 major refurbishment / re-conditioning of already constructed facilities and entire refinery equipment and delivered equipment were performed. Order was given to M/s. Hofficons for refurbishment of above.

Phase 2005-2007: Re-start of Project \& Commissioning of 10.5 MMTPA - With meticulous planning a phase 2 construction schedule, consisting of Utilities \& Primary units with very few 
changes in Phase 1 and secondary process \& despatch facilities with significant modification in Phase II was followed. During the execution of the project several critical activities like erection of one of the world's tallest single crude columns (90 mtr height \& 720 MT weight), shore pulling of $2 \mathrm{~km}$ of 48 " Sub-sea pipeline, and erection of $44 \mathrm{mtr}$. Height DHDS reactor weighing 960 MT were successfully completed. To meet the power requirements, Essar Oil also constructed a 77 MW captive power plant and associated facilities like switchyard \& sub-stations. The year 2007 witnessed the commissioning of all units with associated facilities.

\subsection{Socioeconomic and Development Externalities}

\subsection{Macro benefits:}

It is useful to recapitulate the principal benefits that expansion of the oil sector would bring to economic welfare and social and political conditions prevalent in India. The issues discussed above are at the aggregative or macro-level; those at regional and local levels would be highlighted later. Stability and continued growth of this sector is essential to an expanding economy like India where energy demand has been escalating with economic growth and diversification, intensifying with global reach and changed lifestyles. It is no longer business-asusual for the energy sector. Population growth and rapid urbanization have added fuel to this engine of growth as this sector is one of the principal contributors to the national energy use. Oil and natural gas (hydrocarbons) have both direct and intermediate uses for various sectors of the economy, both as fuel and inputs to these processes. Its universal intermediate character adds weight to its impact on the national economy. India is sitting on a huge shortage compared with its burgeoning demand in the face of limited capacity thus far.

Lack of investment over decades in both hydrocarbons prospecting and refining capacity in the country has resulted in this outcome; both these lines of activity (crude exploration \& production as well as refining capacity) have large gestation lags and risk profiles, especially in oil and gas prospecting. This has resulted in the economy receiving nightmarish jolts when caught napping in the face of ballooning demand for products, especially in middle distillates and overall demand measured in crude throughput. It had several manifestations. Its inflation consequences and 
effects on family budgets are significant and these cause social discontents and disorders which no political system can withstand, let alone a vibrant democracy like India. Inflation effects of oil price hikes may be measured, but it may be elusive to put numbers to the 'multiplier effects' of an orderly society that provides adequate supply lines and infrastructure to reach consumers. It is, however, surmised that the effect would be huge if a metric were to be devised. Analysts believe that a society with discontents may suffer from business confidence, as being not sanguine to investments and high risk capital; and these are matters of great consequence as India prospers as a giant world economic power.

The exchange rate effect of oil shortage is a little more subtle conceptually, though quite large in its result if that could be estimated. The domestic shortage syndrome has two parts, crude and natural gas availability and the products of refinery. Both shortages would be reflected in large trade and current account deficits, and have been large and continues to be so for India. Other than POL, significant contributors to India's trade deficit are gold and diamonds \& precious stones, though the last group is re-exported largely; gold is not due to its insatiable demand in India. Refinery products' shortage increases the net value addition loss in the imports account, and these add up considerably. Additionally, refineries bring in their downstream products which are also lost in terms of their value additions and multiplier effects. Imagine a situation where India imported not gold ingots but also all the jewellery from abroad if there were no jewellers at home. Some powerful examples from steel and automobiles industries were cited above to drive home the point. The effect of refineries are similar and additionally all the downstream industries they spawn in different layers. The current account deficits that translate into BOP deficits put pressure on the exchange rate, and these could be harmful to domestic consumers, especially for imported goods which become costlier. A direct consequence, among others, is that imported crude and products in turn become costlier as they are always denominated in international currencies like the US dollars. They in turn have inflationary effects discussed above.

It was also emphasized that hydrocarbons are universal intermediates permeating all other economic activities. Hence, much beyond its inflation, exchange rate and social order outreach, this source of energy is critical to growth of agriculture, petrochemicals, fertilizers, power generation and to several others. These downstream industries which develop alongside refineries support the location and growth of these new activities. To give specific examples, the proliferation of industries producing plastics, packaging, apparel, among many other petrochemical products, are now prominent and pervasive even in rural India; it is not just the frequently cited transport industry that is the beneficiary of this sector. Its growth, though strenuous over the decades, has fuelled all round development of India. It was pointed out that 
refineries spawn other industries which form a chain for petrochemicals. This underlines the independent standing of refineries as an engine of growth even when domestic sourcing of crude oil is limited; when domestic prospecting and production is added, the chain gets even stronger. Furthermore, India's food security through the much recorded green revolution in the IndoGangetic plains and coastal peninsula would have been a pale shadow of its achievements without generous dozes of subsidized inputs in all of which hydrocarbons have played important roles, be they irrigation (diesel generated pump sets), fertilizers, tractors, power tillers, harvesters, etc. Food security apart, the income generated in the regions and prosperity of farmers were enormous. Crude oil and natural gas as much as refineries are important cogs in that wheel of India's growth. Thus to perceive the economic multiplier effects of this sector legitimately, we need to consider the total economy for externalities, and not just their neighbourhoods of activity for ripple effects. These are aggregative and macroeconomic effects of the sector, which make considerable splash.

\subsection{Local and Regional effects}

It is clear from the above description that there were three types of contracts involved in setting up the massive refinery and its construction work. These can be classified into international, national and local level multipliers. $\mathrm{ABB}$ as the main Project Management Consultant (PMC) procured the necessary technology, design features and specialised equipment from international sources. To that extent, the import content did not result in multipliers for neither national nor local economies. At the next level there were national level sub-contractors (NESs), and their implementation of detailed projects generated both national and local multipliers, and undoubtedly some import contents. These are discussed in outline below. The macro effects at the national level are recapitulated in the preceding section.

During the construction, commissioning and operations of the refinery, massive labour employment, both skilled and unskilled, was generated in the market. This Project also generated the secondary employment for other business like transport, manufacturing, power, market for the daily consumption by the labour, housing \& construction in Jamnagar for the staff mobilized to administer $\&$ manage such a vast labour force.

Residents of the surrounding villages not only got the advantage of high value paid for their land compared to the existing market rate at that period of time. They also benefitted from the secondary businesses like shops, vehicles hired by Essar, various types of shops which were used by the labour work force etc. that resulted from activities generated. Apart from these, employment opportunities to the villagers also materialised. Facilities on education, healthcare 
and other forms of opportunities for the development of region and their capabilities were developed alongside. Some of these activities are presented in Annex 1.

\subsection{Review of literature}

Large scale infrastructure projects like oil refineries demands a comprehensive tool like Cost Benefit Analysis toward decision making in efficient allocation of finite resources. In its simplest form, CBA is a tool to evaluate the identifiable benefits and costs associated with a project and the appreciable externalities associated with a given project. Cost Benefit Analysis originated at the French École National des Ponts et Chaussées (Dupuit, 1844). French engineer Jules Dupuit discussed the subject as early as 1844 . While seeking a criterion of the value to society of public works such as roads, canals, bridges and water works, he pointed out that if necessary, many users would pay more than they actually would have paid for the service. This in essence, is known as consumer surplus, which was later developed by Marshall, Hicks, Caldor and others.

The practical use of CBA began with water resources development in the USA in 1930s with the introduction of the Flood Control Act, 1936. This Act laid down the test that a project was feasible if the benefits are in excess of the estimated costs. In UK the use of CBA came later and has been used mainly in the field of transportation, e.g. studies of new underground railway lines in London and of motorways, etc.

CBA is much easier to apply, as receipts and expenditures offer a better basis for estimation. Simultaneously, it can also be ascertained that market prices reflect social costs and benefits reasonably well, and, therefore, presents a possible explanation of the less frequent use of CBA in developed countries.

Cost benefit analysis is concerned with the theory and application of criteria for appraising the desirability of investment decisions in the public sector, in terms of national objectives (Chawla, 1987). The fundamental economic problem facing most nations is the optimal allocation of scarce resources in competing projects. This involves making a rational choice between various alternative projects and selecting the best possible one according to the criterion of maximization of net societal benefit. Social Cost Benefit Analysis (SCBA) of projects should aim to establish two national objectives, increasing the total national income (growth objective) and improving the income distribution so as to make it more egalitarian (equity objective). The other objectives of SCBA are ensuring that a selected project subscribes to employment generation, self-reliance, balanced regional development, protection and improvement of environment.

Projects are to be evaluated by the extent to which they contribute to (benefits) or detracts from (costs) from the national objectives. If benefits exceed costs, the project is acceptable. The benefits are defined in terms of their national objectives, whereas the costs are opportunity cost, which is the benefit foregone by not using these resources in the next best investment decision available. The benefits foregone can be re-defined in terms of their impact on national objectives. In an ideal condition, where every information pertaining to competing alternative projects are available, the investments are usually made to the best possible projects. 
CBA is a tool which helps to assess whether benefits accrued from a project are in excess of its social costs. This makes the project represent a net benefit to the whole society. The key strength of this approach is that it produces information of the project's net contribution to the society, summarized into simple indicators, such as the economic net present value (ENPV).

The scale and scope of megaprojects like oil refineries and their huge investment schedule necessitates to carefully assess the benefits and costs associated with large scale projects (Flyvbjerg, Bruzelius, \& Rothengatter, 2003; Nash, 1991). In the recent past it has also been observed that governments in some countries and donor bodies have almost made it mandatory to include $\mathrm{CBA}$ as a formal process to evaluate the performance of large scale projects ((EC, 2008; OECD, 1969; UNIDO, 1972; World Bank, 1975; and Mishan and Quah, 2007). CBA as a tool can be used either to appraise or to evaluate a given project. Appraisal is done before the commencement of the project and evaluation is done after the completion of the project. The gaining importance of $\mathrm{CBA}$ as a policy making tool as also received endorsements by leading economists and the World Bank (World Bank, 2004; Ninan, 2008). In this regard, it may be worthwhile to mention that extant literature refers CBA as the "single most important problemsolving tool in policy work" (Munger, 2000).

\subsection{Social Cost Benefit Analysis: methodology in outline}

Before we launch into the detailed analysis, a brief account of the methodology of the social cost benefit analysis would be useful. Social Cost Benefit Analysis (SCBA) provides an overall picture of the distributive effects, alternatives and uncertainties. Cost Benefit Analysis is a framework that identifies, quantifies and compares the aggregate benefits and costs associated with a policy or a production process. The underlying philosophy of SCBA is benefits enhance the human life and the quality of living, whereas costs tends to reduce the same. For a project like Essar Oil Refinery at Vadinar to qualify as a net benefit for the economy and society, the social benefits, like direct and indirect job creation, increasing economic activities in the local, regional and national economy, multiplier effects and positive externalities must outweigh the net costs. The challenge in SCBA is often to monetize the benefits and costs and appropriate conversion factors are employed to convert financial values to their economic counterparts. The rationale for using CBA is to illustrate the gains and losses of a given action in a broader societal context, and to look at who receive the benefits and who incur the costs. The societal approach avoids solely restricting the impacts to reflect a single group of stakeholders' interests.

The noted economists Frank and Bernanke laid CBA as one of the seven core principles of Economic Sciences. CBA as a tool can be used either to appraise or to evaluate a given project. Appraisal is done before the commencement of the project and evaluation is done after the completion of the project. This study focuses on Essar Oil's already operational Vadinar 
Refinery Project. Therefore, technically, this work should be an evaluation of the project. However, the process of analysis is both retrospective as well as prospective. It is retrospective in the sense that the project is already completed and it has become fully operational. It is prospective in the way that by evaluation of the relative merits of the project in terms of the accrued benefits and costs, it serves as a template for deciding a fresh course of equity investment in refinery infrastructure augmentation. It has already been informed by EOL of new investment and this analysis will aid in appreciation of the strategic direction of the project as well as its overall fit in the broader socioeconomic rubric.

Formally, the analysis entails solving the following equation:

$N S B=\Sigma .\left(R_{t}-C_{t}\right) /(1+r)^{* *} \mathrm{t} \ldots(1)$

with $\mathrm{t}=1,2, \ldots \mathrm{n}$

where NSB is net social benefit, Rt is revenues generated from sale of the products in year $\mathrm{t}, \mathrm{Ct}$ is the cost of refining in the corresponding year $t, r$ is the discount rate, $t$ is the reference year, and $\mathrm{n}$ is the number of years in the project; ${ }^{* *}$ is the power operator. The CBA analysis is conducted following generic steps of $\mathrm{CBA}$ as described below.

In accordance with European Commission Guidelines to CBA (2008), the framework of SCBA for EOL's Vadinar Refinery is construed. The analysis is based on the following stages. Firstly, the financial cost and revenue data are converted from financial prices to accounting or shadow prices by applying explicit conversion factors. Secondly all non-market impacts have been monetized by the notion of Willingness to Pay (W'TP) or Willingness to Accept (W'TA), which is grounded on the concept of Consumer Surplus (CS) or Producer Surplus (PS). This, in turn, is expressed quantitatively by the Rule of Half. The process of determination of CS and PS involves identifying and quantifying the non-monetized costs and benefit streams associated with the project to generate the specific values of CS and PS. In the next stage, the externalities of the project are duly incorporated in the analysis. This is followed by the determination of the Social Discounting Rate for India using the Social Time Preference Rate (STPR) approach. The final stage involves calculation of economic performance indicators like ENPV, ERR and the most critical performance criteria for project evaluation, namely the BCR for the project.

The following stages are followed in presenting the analysis.

\subsection{Analysis}

\subsubsection{Financial Analysis}


According to the UNIDO Guidelines' Stage I, financial analysis produces an estimate of the project's financial profit or the net present value (NPV) of the project when all inputs and outputs are measured at market prices. According to the UNIDO Guidelines, the methodology used for the determination of the financial returns in Cost Benefit Analysis is the Discounted Cash Flow (DCF) approach. This implies following assumptions:

(i) Only cash inflows and outflows are considered (depreciation, reserves and other accounting items which do not correspond to actual flows are disregarded).

(ii) The determination of the project cash flows should be based on the incremental approach.

(iii) To calculate the present value of the future cash flows the adoption of an appropriate financial discount rate is required. The financial discount rate reflects the opportunity cost of capital, defined as 'the expected return forgone by bypassing other potential investment activities for a given capital' (EC Working Document No. 4: Guidance on the methodology for carrying out Cost Benefit Analysis). The discount rate is in effect an 'exchange rate' between value today and value in the future (Handbook of Cost Benefit Analysis, Commonwealth of Australia, 2006).

The Financial Discount Rate (FDR) is the opportunity cost of capital. The benchmark for an infrastructure project may be the real return on Government bonds (the marginal direct cost of public funds), or the long-term real interest rate on commercial loans, or a weighted average of the two rates. In order to arrive at the financial discount rate to be used for financial analysis of EOL, we consulted several sources of information available on the public domain. The initial frame of reference was the 10 Year Yield on Government Bond that would serve as a benchmark for the standardized interest rate on Government securities. Since the discount rate is pegged to the rate of interest, therefore this is a fairly approximate way to arrive at the discount rate at current prices, assuming we are considering the nominal rate of interest (According to EC Guide, it is recommended to use nominal prices in financial analysis and a nominal financial discount rate must be used with current prices). The India Government Bond 10Y increased to 7.86 percent in April 2015 from 7.73 percent in March of 2015. The India Government Bond 10Y averaged 9.19 from 1994 until 2015, reaching an alltime high of 14.76 in April of 1996 and a record low of 4.96 in October of 2003. To remain relevant and contemporary, we have assumed the FDR as $8.4 \%$ taking the historical average from 1968 till 2015. 


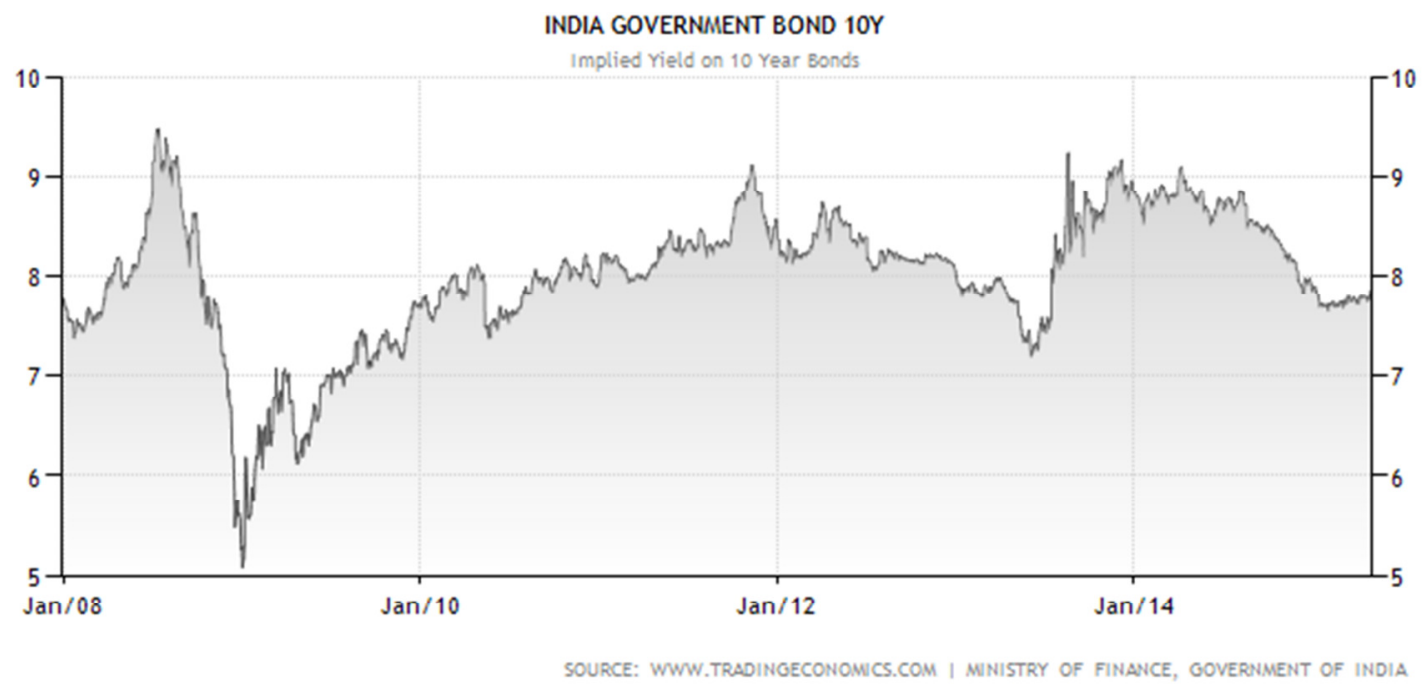

Chart 1: Indian Government Implied Yield on 10 Year Bonds (Source: http://www.tradingeconomics.com accessed on 01 May 2015)

\section{Total Investment Costs}

The total investment costs are worked out under the following categories:

(a) Total Fixed Assets

(b) Total Startup Costs

(c) Variation in Working Capital

The investment cost figures are obtained from the Balance Sheet of EOL, as obtained from the Annual Reports of the company. The costs are shown with a negative sign as they are considered to be outflows on the part of the operator of the refinery project.

The variations of working capital indicate an investment outlay for the project and are included as a part of the Total Investment Cost. The Total Investment Cost for the project works out to be the sum of the total fixed cost, total start-up cost and variation in working capital. 


\begin{tabular}{|c|c|c|c|c|c|c|}
\hline Total Investment Costs & & & & & & \\
\hline (IN INR CRORES) & & & & & & \\
\hline & 2009 & 2010 & 2011 & 2012 & 2013 & 2014 \\
\hline Land & -59 & -139 & -142 & -146 & -152 & -156 \\
\hline Buildings & -356 & -398 & -406 & -736 & -752 & -766 \\
\hline Plant \& Machinery & -12677 & -12943 & -13082 & -23085 & -24293 & -24946 \\
\hline Office Equipments & -35 & -44 & -50 & -56 & -57 & -50 \\
\hline Furnitures and Fixtures & -8 & -16 & -16 & -18 & -19 & -20 \\
\hline Vehicles & -8 & -9 & -10 & -12 & -13 & -13 \\
\hline Aircraft & $\mathbf{0}$ & -10 & -10 & -10 & -10 & -10 \\
\hline Total fixed assets (A) & -13143 & -13559 & -13716 & -24063 & -25296 & -25961 \\
\hline Softwares \& Licenses & -30 & -32 & -35 & -48 & -55 & -65 \\
\hline Patents & 0 & 0 & 0 & 0 & 0 & 0 \\
\hline Other pre-production expenses & 0 & 0 & 0 & 0 & 0 & 0 \\
\hline Consulting Services & -12 & -4 & -27 & -32 & -10 & -13 \\
\hline Training expenses & 0 & 0 & 0 & 0 & 0 & 0 \\
\hline R\&D expenses & 0 & 0 & 0 & 0 & 0 & 0 \\
\hline Total start-up costs (B) & -42 & -36 & -62 & -80 & -65 & -78 \\
\hline Current Assets (receivables, stocks, cash) & & & & & & \\
\hline Current Liabilities & & & & & & \\
\hline Net Working Capital & & & & & & \\
\hline Variations in W orking Capital (C )* & -1701 & -3989 & -7841 & -774 & -865 & -1315 \\
\hline${ }^{*} \mathrm{CWIP}$ including EDC and Adv on Cap A/c & & & & & & \\
\hline Total investment costs $(A)+(B)+(C)$ & -14886 & -17584 & -21619 & -24917 & -26226 & -27354 \\
\hline
\end{tabular}

Chart 2: Total Investment Costs

\section{Total operating costs and revenues}

The second step in financial analysis is the calculation of the total operating costs and revenues. The operating costs consist of those items which are purchased as goods and services. They are not considered as investment items as they are consumed in the same accounting year of purchase.

The basic assumptions made in calculating the total operating costs and revenues are as follows:

1. A discount rate of $8.4 \%$ has been considered for all discounting calculations

2. Depreciation has been excluded in the calculation as it is not an effective cash payment

The NPV of all inflows and all net outflows have been estimated based on discounting till 2014. 


\begin{tabular}{|c|c|c|c|c|c|c|}
\hline Operating Costs and Revenues & & & & & & \\
\hline (IN INR CRORES) & & & & & & \\
\hline & 2009 & 2010 & 2011 & 2012 & 2013 & $2014 *$ \\
\hline Cost of raw materials consumed & -32560 & -32856 & -42129 & -52895 & -81334 & -88824 \\
\hline Purchase of traded goods / petroleum products & -651 & -1706 & -1964 & -1957 & -867 & -1276 \\
\hline Employee benefits expense / Salary Cost & -97 & -98 & -120 & -135 & -186 & -225 \\
\hline Other expenses / Operating Expenses & -2198 & -1090 & -1507 & -2662 & -3387 & -4297 \\
\hline Finance costs & -1091 & -1181 & -1220 & -1387 & -3424 & -3218 \\
\hline Exceptional items & -1139 & -961 & -1083 & -1237 & -111 & 0 \\
\hline Repairs \& Maintenance & -32 & -58 & -47 & -119 & -121 & -127 \\
\hline Rent & -15 & -10 & -11 & -17 & -20 & -23 \\
\hline Total operating costs & -37736 & -37892 & -48023 & -60273 & -89309 & -97840 \\
\hline Total Operating Revenue & $37,700.15$ & $37,376.54$ & $47,342.21$ & $58,761.39$ & $89,186.90$ & $99,472.56$ \\
\hline Net operating revenue & -35.85 & -515.46 & -680.79 & $-1,511.61$ & -122.10 & $1,632.56$ \\
\hline
\end{tabular}

Chart 3: Operating Costs and Revenues

\section{Financial Return on Investment}

After completion of the tables on Total Investment Costs and Operating Costs and Revenues, the next step in the financial analysis is to arrive at the Financial Return on Investment. In order to evaluate the Financial Return, there are two major indicators to be determined:

(a) Financial Net Present Value (FNPV)

(b) Financial Rate of Return (FRR)

The European Guide to CBA (2008) defines Financial Net Present Value as the sum that results when the expected investment and operating costs of the project (suitably discounted) are deducted from the discounted value of the expected revenues.

In mathematical notation, FNPV can be expressed as

$$
\mathrm{FNPV}=\sum_{t=0}^{n} a_{t} S_{t}=\frac{S_{0}}{(1+i)^{0}}+\frac{S_{1}}{(1+i)^{1}}+\ldots+\frac{S_{n}}{(1+i)^{n}}
$$

Where $S_{t}$ is the balance of cash flow in time $t$, and at is the financial discount factor chosen for discounting at time t.

The FNPV is calculated as follows:

$$
F N P V=\sum\left[S_{t} /(1+F R R)^{t}\right]=0
$$

The calculation of the Financial Return on Investment measures the capacity of the Net Revenues to remunerate the Net Investment Costs. 


\begin{tabular}{|c|c|c|c|c|c|c|}
\hline \multirow{3}{*}{ Evaluation of the Financial Return on Investment } & (IN INR CRORES) & & \multirow[b]{2}{*}{ YEARS } & & \multirow[b]{3}{*}{2013} & \multirow[b]{3}{*}{2014} \\
\hline & & & & \multirow[b]{2}{*}{2012} & & \\
\hline & \multicolumn{2}{|l|}{2009} & 2011 & & & \\
\hline Total operating revenues & $37,700.15$ & $37,376.54$ & $47,342.21$ & $58,761.39$ & $89,186.90$ & $171,764.56$ \\
\hline Total inflows & 37700.15 & 37376.5 & 47342.2 & $\mathbf{5 8 7 6 1 . 4}$ & 89186.9 & 171764.6 \\
\hline Total operating costs & -37736 & -37892 & -48023 & -60273 & -89309 & -97840 \\
\hline Total investment costs & -14886 & -17584 & -21619 & -24917 & -26226 & -27354 \\
\hline Total outflows & -52622.00 & -55476 & -69642 & -85190 & -115535 & -125194 \\
\hline Net Cash Flow & -14921.85 & -18099.5 & -22300 & -26429 & -26348 & 46570.56 \\
\hline & & & & & & \\
\hline & & & & & & \\
\hline & & & & & & \\
\hline Discount Rate & & & & & & \\
\hline $\begin{array}{l}\text { Note: A discount rate of } 8.4 \% \text { has been applied to calculate } \\
\text { the value }\end{array}$ & & & & & & \\
\hline Financial Net Present Value of the Investment - FNPV (C) & (1822.90) INR CRC & DRES & & & & \\
\hline
\end{tabular}

Chart 4: Financial Net Present Value of Investment

In our calculation FNPV (C) is $\mathbf{- 1 8 2 2 . 9 0}$ INR Crores, by applying a discount factor of $8.4 \%$. It is observed that though the FNPV (C) is negative, however, the project breaks even in 2014. The PAT, standing at -1180 INR Crores, which was negative in 2013, stood at 126 INR Crores, in a whopping positive turnaround. The Gross Revenue changed by $10.27 \%$ between 2013 and 2014, so did the CP GRM by $0.4 \%$ and EBIDTA by $28.8 \%$ between 2013 and 2014 . It is interesting to observe that Financing Cost has decreased by $6.0 \%$, signaling the increased efficiency and economies of scale for the refinery. Operationally, in 2013, EOL launched the "Optima Plus" programme, designed to enhance refining margins by an additional $\sim$ US $\$ 1.0 /$ bbl over the next three years.

We have modeled the growth of Gross Revenue, EBIDTA and CP GRM till 2016. Using second order polynomial curve fitting, it is observed that all three performance indicators stands to gain positively in the near short - term movements. The auto - regressed variables shows strong interdependencies in their movement and reflects the impact of lagged endogenous variability in the output. This is shown in the charts below. The results conclusively demonstrates that the project is financially sustainable and will achieve positive FIRR and FNPV shortly. 


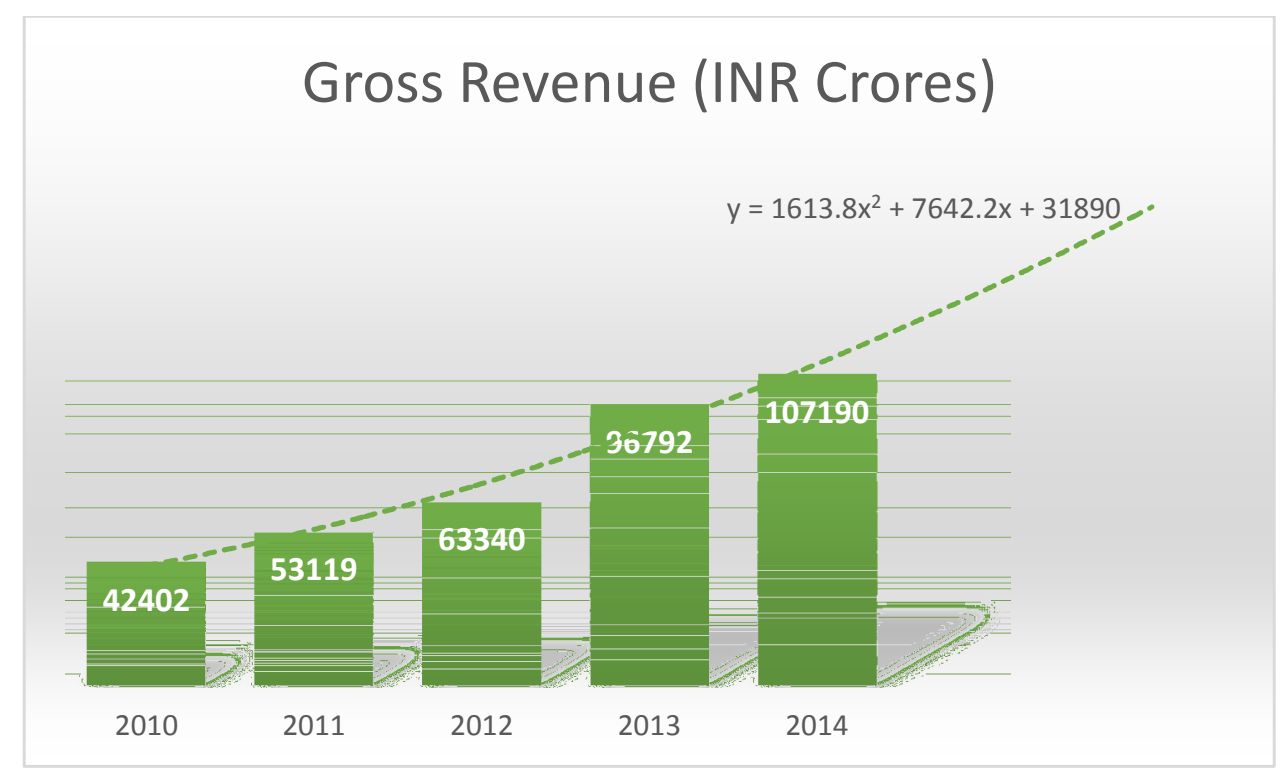

Chart 5: Polynomial Forecasting for Gross Revenue (INR Crores)

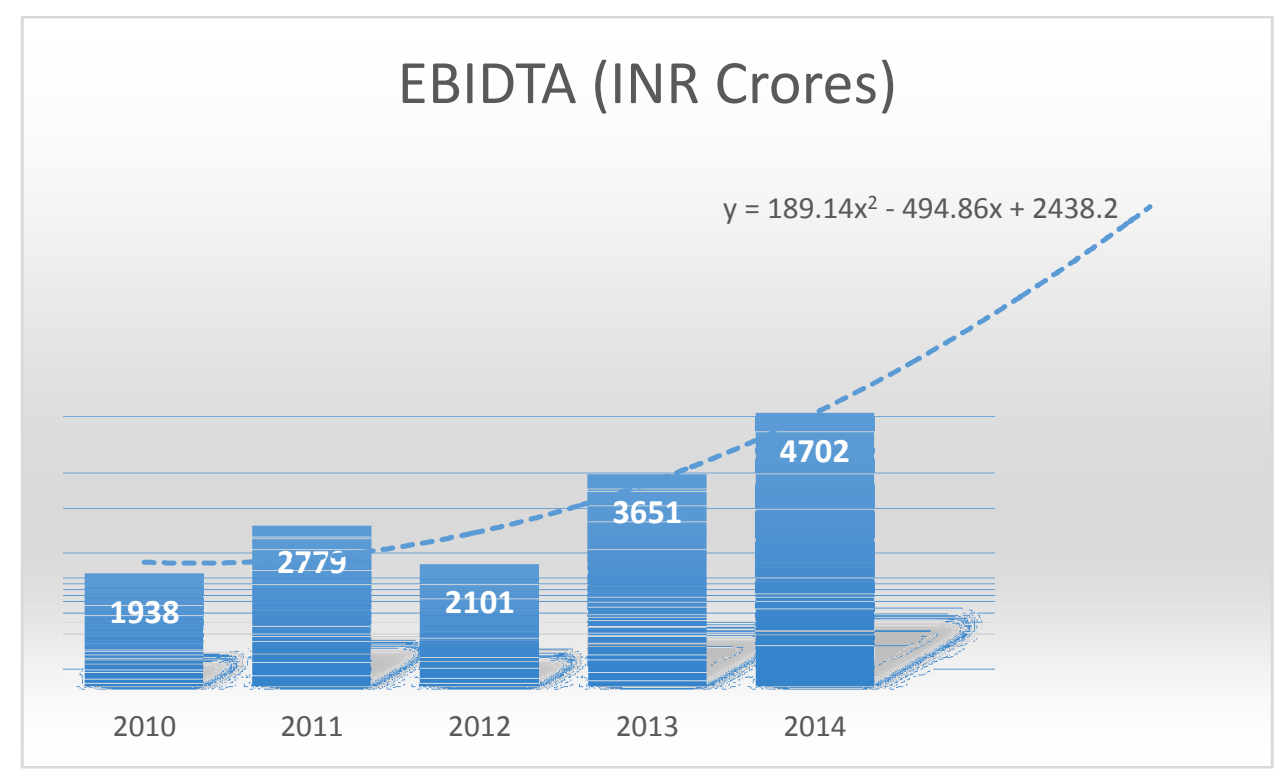

Chart 6: Polynomial Forecasting for EBIDTA (INR Crores) 


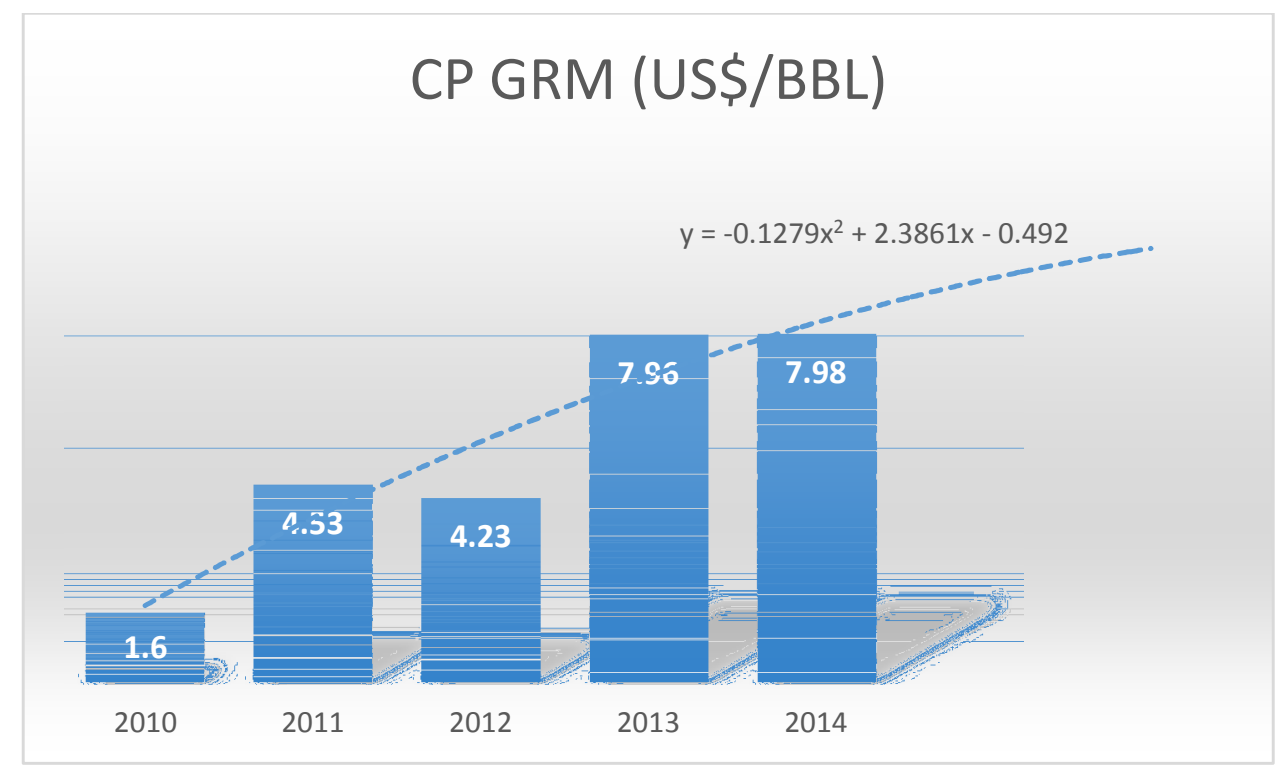

Chart 7: Polynomial Forecasting for CP GRM (US\$/BBL)

\subsubsection{Economic Analysis}

\section{METHOdology: FROM Financial ANALYsis TO ECONOMIC ANALYSIS}
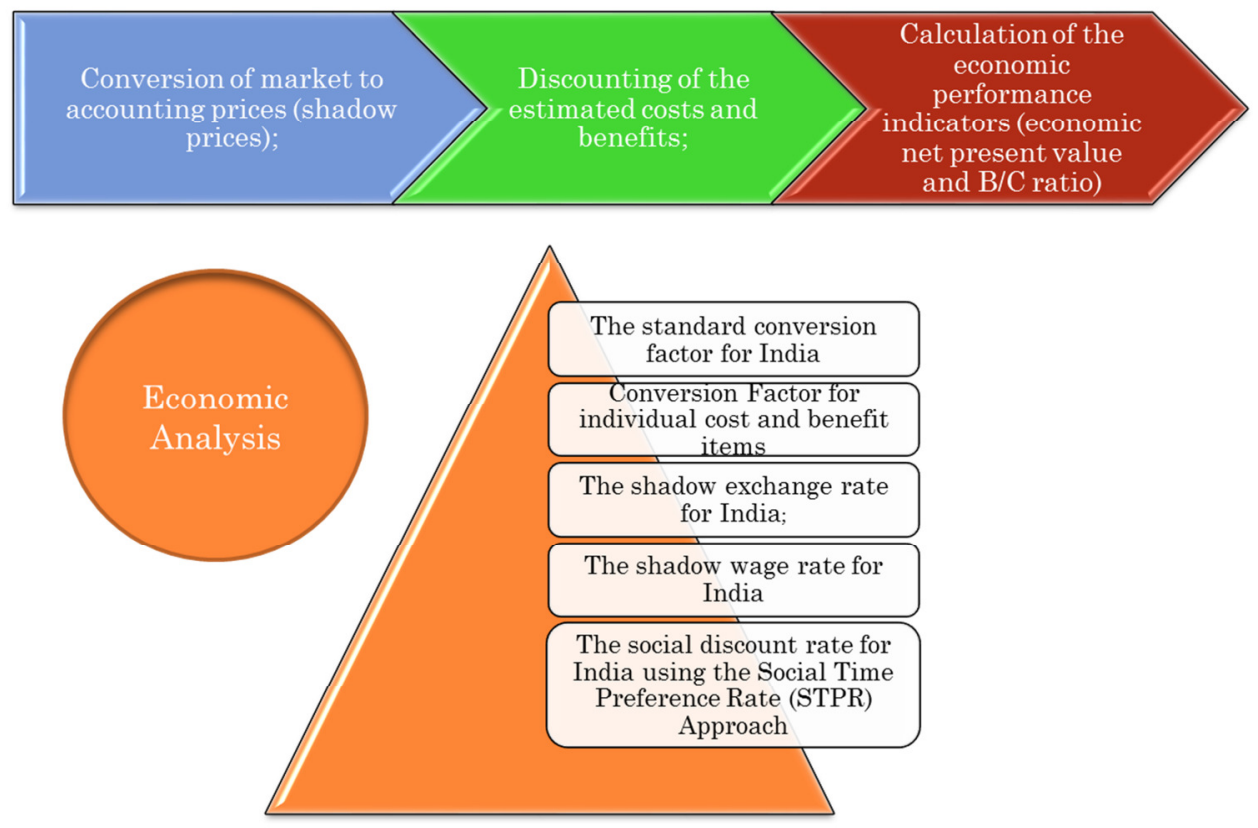

Figure 1: Financial Analysis to Economic Analysis

In the cost benefit appraisal of EOL, the financial analysis of the project is followed by economic analysis (Figure 1). The analysis draws its merit from the concepts of consumers' surplus and rents, the distinction between benefits and transfer payments, the concept of shadow pricing, external economies and diseconomies, the choice of investment criteria and the problems of uncertainty are adequately covered in the succeeding sections. 
The economic analysis is distinctly different from the financial analysis with respect to benefits accrued as a result of the project. Whereas the latter is merely concerned with the owners or promoters of the project, economic analysis attempts to identify the project's impact on the society at large.

\section{Consumer's Surplus}

According to Alfred Marshall (1925), the consumer's surplus is the maximum sum of money the consumer would be willing to pay for a given amount of the good, less the amount he actually pays. The consumers of a refinery project are the oil marketing companies and other agencies who buys finished products. According to the Annual Report of EOL for the FY 2013 - 14 (page 22), Essar Oil has product off take and infrastructure sharing agreements with all oil PSUs (the state-owned public sector units). These include Bharat Petroleum Corporation Ltd. (BPCL), Hindustan Petroleum Corporation Ltd. (HPCL) and the Indian Oil Corporation Ltd. (IOCL). Essar Oil also offers a wide range of products to bulk customers in the industrial (cement, power, chemicals, construction, fertilizers, etc.) and transport sectors. Besides, EOL has also received approvals to supply ATF to the Indian Armed Forces. Essar Oil has an extensive network of about 1,400 operational retail fuel outlets across the country. EOL also stands to gain by lowering the cost of fuel supplied to their retail network, by entering into agreements with various public sector OMCs enabling to source products from their refineries and depots. This would also result in Opex savings for the company.

\section{Producer Surplus}

Estimating the producer surplus, the revenue above the long-run average cost, is an important part of social cost-benefit analyses of changes in petroleum use. In case of EOL, Producer Surplus is obtained by learning curve effect, economies of scale and efficient management practices.

\section{Government Surplus}

Government has a direct interest in oil consumption because it generates tax revenues. These revenues can then be used to cut other taxes. However, we first consider these revenues as accruing to the Government, even though they are likely to be retroceded to consumers over time. The variation of tax revenues for the government can be calculated with the following formula. In algebraic form:

$\Delta \Phi=\mathrm{T}_{2} \mathrm{Q}_{2}-\mathrm{T}_{1} \mathrm{Q}_{1} \ldots$ (4)

Where $\Delta \Phi$ is the variation in tax revenue. In the case of EOL, we have seen that there is progressive and substantial increase in tax revenue from 2009 - 2010 onwards. 


\section{Externalities for EOL}

To make a reasonably good Economic Analysis, it is equally important to consider the externalities that are not accounted for in the converted financial inputs and outputs. The sum total of the spillover effects as a result of the EOL's Vadinar Refinery megaproject is considered based on the direct, indirect and induced impact generated by construction phase and operational phase (till March 2015) of EOL. The qualitative aspects of these spillage effects have been attempted to capture under the umbrella of quantitative analysis. For calculation of the externalities, we have taken the onsite labour impacts during the construction phase; and the Local Revenue and Supply Chain Impacts and Induced Impacts in the Operational Phase. Using data obtained from EOL and data available from Petroleum Planning and Analysis Cell (PPAC), Ministry of Petroleum and Natural Gas, the externalities are computed through the Petroleum Refinery Jobs and Economic Development Impact (JEDI) Modeling Technique of the U.S. Department of Energy Office of Energy Efficiency \& Renewable Energy. Wherever possible, in the absence of actual data, realistic assumptions are made or comparables are used as proxy measures of the reality.

\section{Choice of Social Discount Rate}

The Asian Development Bank defines the social discount rate "as a reflection of a society's relative valuation on today's well-being versus well-being in the future." There is wide diversity in social discount rates, with developed nations typically applying a lower rate $(3-7 \%)$ than developing nations $(8-15 \%)$.

In our estimate, we have used the Social Time Preference Rate (STPR) Approach to arrive at the social discount rate for India.

The algebraic expression for the same as expressed by Ramsey formula is as follows:

$$
\mathrm{r}=\varepsilon g+\mathrm{p} \ldots(5)
$$

Where $\mathrm{r}=$ Social Discount Rate

$\varepsilon=$ Elasticity of Marginal Utility with respect to Consumption

$\mathrm{g}=$ Growth Rate of Public Expenditure

$\mathrm{p}=$ Rate of Pure Time Preference

Applying the values for the variables as above, we have,

$\mathrm{r}=((1.64) *(5.3))+(1.3)$

$$
=9.99 \% \sim 10 \%
$$

ADB have also recommended SDR for India in the range of $10-12 \%$ depending on the project. A high SDR is usually taken for small projects with immediate benefits. For megaprojects like oil 
refineries, a low SDR is preferred, since the benefits are accrued over a period of time. Thus, our estimate of SDR for India as $10 \%$ seems to be reasonably appropriate.

\subsection{Results of CBA: Estimation of ENPV and B/C Ratio}

To arrive at the Economic Analysis for EOL, the conversion of elemental costs of investment and operation are required from the financial values to economic values using appropriate conversion factors.

The abridged economic analysis for EOL calculated till 2014 is shown below.

\begin{tabular}{|c|c|c|c|c|c|c|c|c|}
\hline & & \multicolumn{5}{|c|}{ ECONOMIC ANALYSIS OF ESSAR OIL } & & \\
\hline & & & & & & & & \\
\hline \multicolumn{2}{|l|}{ BENEFITS } & 2008 & 2009 & 2010 & 2011 & 2012 & 2013 & 2014 \\
\hline Total Consumers Surplus & & & 12680.226 & 1823.46 & 14479.3 & 12943.04 & 21182.48 & 18649.14 \\
\hline Total Producers Surplus & & & 6144.205 & 4267.4 & 562.235 & 10036.33 & 15924.08 & 57707.91 \\
\hline Total Government Surplus & & 1182.5982 & 3262.13097 & 3723.724 & 4550.07 & 3836.261 & 4548.8328 & 10089.27 \\
\hline Externalities & & 130774.62 & 146264.02 & 26530.44 & 26738.3 & 26946.24 & 27301.54 & 63702.28 \\
\hline Total Benefits & & 131957.218 & 168350.582 & 36345.02 & 46329.9 & 53761.87 & 68956.933 & 150148.6 \\
\hline & & & & & & & & \\
\hline & & & & & & & & \\
\hline Total Investment Costs & & & -7121.14 & -9635.88 & -13581.84 & -10743.02 & -11320.07 & -12053.12 \\
\hline Total Operating Cost & & & -22014.46 & -22768.7 & -28835 & -35886.7 & -52544.08 & -57706.9 \\
\hline Total Cost & & & -29135.6 & -32404.5 & -42417 & -46629.7 & -63864.15 & -69760 \\
\hline NET BENEFITS & & 131957.218 & 139214.982 & 3940.484 & 3913.1 & 7132.149 & 5092.7829 & 80388.59 \\
\hline & & & & & & & & \\
\hline & & & & & & & & \\
\hline BCR (TB/TC) & 2.31 & & & & & & & \\
\hline BCR (BY NPV MITHOD) & 2.38 & & & & & & & \\
\hline ENPV & INR 289203.36 CRORES & & & & & & & \\
\hline
\end{tabular}

Chart 8: Economic Analysis of EOL

The Economic Performance Indicators of EOL is given below.

Economic Net Present Value (ENPV): INR 289203.36 Crores (2008 - 2014)

B/C Ratio (2008 - 2014): 2.31

B/C Ratio (2008 - 2014): 2.38 (Using NPV Method)

\subsection{Comparative Analysis of Project BCRs}

The healthy financial and economic indicators point to the fact that the project has been viable, both in the short-term as well as in the future horizon. A comparative analysis of similar projects across the country and overseas yields quite analogous results. 


\begin{tabular}{|l|l|l|l|l|l|}
\hline Project & $\begin{array}{l}\text { Western } \\
\text { Freeway } \\
\text { Sea Link }\end{array}$ & $\begin{array}{l}\text { Bandra } \\
\text { Worli Sea } \\
\text { link }\end{array}$ & $\begin{array}{l}\text { MRTS, } \\
\text { Thane }\end{array}$ & $\begin{array}{l}\text { Multimodal } \\
\text { International } \\
\text { Passenger and } \\
\text { Cargo Hub Airport } \\
\text { at Nagpur }\end{array}$ & $\begin{array}{l}\text { Mumbai-Pune } \\
\text { Expressway; } \\
\text { Mumbai } \\
\text { Trans } \\
\text { Harbour Link }\end{array}$ \\
\hline BCR & 1.74 & 1.79 & 2.53 & 1.61 & 1.43 \\
\hline
\end{tabular}

Chart 9: Comparative analysis of national projects (It may be noted that for Delhi International Airport Limited the BCR was estimated at 3.78 (Chaudhuri et al., 2015)

\begin{tabular}{|c|c|c|c|c|}
\hline $\begin{array}{l}\text { The Port of } \\
\text { Anchorage } \\
\text { (POA), Inter- } \\
\text { modal } \\
\text { Expansion } \\
\text { Program, } \\
\text { Alaska, } 2011\end{array}$ & $\begin{array}{l}\text { Roadway } \\
\text { Rehabilitation } \\
\text { Project, Romania, } \\
2011\end{array}$ & $\begin{array}{l}\text { City } \\
\text { Development } \\
\text { Project, Italy, } \\
2011\end{array}$ & $\begin{array}{l}\text { Portsmouth/Kitte } \\
\text { ry } \\
\text { Memorial Bridge } \\
\text { Replacement } \\
\text { Project, New } \\
\text { Hampshire }\end{array}$ & $\begin{array}{l}\text { State Highway } \\
\text { Investment in } \\
\text { New Zealand, } \\
2010\end{array}$ \\
\hline $\begin{array}{l}2.5 \text { (With } \\
\$ 527 \mathrm{M} \\
\text { Federal } \\
\text { Grant; } 1.3- \\
1.8 \text { (Without } \\
\text { Grant) }\end{array}$ & 1.002 & 2.748 & 1.6 & 2.04 \\
\hline
\end{tabular}

Chart 10: Comparative analysis of international projects (It may please be noted that Oil Transportation Network: East West Link, prepared by the Victoria State Government, Australia, a BCR of 1.4 , having over $\$ 1.4$ billion of net economic benefit and an internal rate of return of 9 per cent has been observed).

\subsection{Limitations of the Study}

The major limitation of the assignment was the short time frame used in analysing the data. There is a great scope to refine and improve the results. Investment Costs and Operating Costs and Revenues data are available till December 2014 (unaudited). Taking Y-O-Y growth of the cost figures, a more realistic FNPV, ENPV and BCR could have been estimated. Also, a detailed analysis of the product wise demand estimates and their TPP could have yielded better Consumer Surplus information. The future growth of benefits including Producer Surplus, Government Surplus and Externalities could have been still better captured by modelling using polynomial curve fitting. All these perhaps would be ascertained in the second phase of the project, which the authors would concentrate subsequent to the submission of this report. There is also much larger scope to improve the numbers of the externalities resulting from the local revenues, supply chain impact and induced impacts generating from the refinery project. 


\subsection{Summary and Future Scope}

The assignment presents a comprehensive analysis of the benefits and costs associated with the EOL Refinery at Vadinar in Gujarat. The benefits include not only the financial gains of the stakeholders in the system, but also the economic gains to the local, regional and national economy as a result of the increase in social welfare created by the EOL Refinery. Using a Social Discount Rate (SDR) of $10 \%$ as estimated here, the Economic Performance Indicators of EOL are obtained as Economic Net Present Value (ENPV) and Benefit Cost Ratio (BCR) for the Time Phase 2008 - 2014.

Asian Development Bank (2011) observed that "countries differ in economic structure, capital scarcity, stage of financial development, efficiency of financial intermediation, impediments faced in accessing the international capital market, and social time preference." These differences result in varying SDRs and BCRs for refinery projects around the world. It may be worthwhile to examine the choice of social discount rates and the corresponding BCR for refinery projects across developed and developing economies to affirm the soundness of the results obtained in the CBA for EOL's Vadinar Refinery.

The project has positive economic net present values and benefit-cost ratios well in excess of one. Literature review using CBA done by Canadian Energy Research Institute (CERI, 2014) and National Renewable Energy Laboratory (Goldberg, 2013) in USA for many oil pipeline networks and refineries have demonstrated similar results in CBA. The financial and economic benefits have therefore been well justified in the results. The CBA of project EOL proves that the project is economically viable and financially sustainable. In finale, there is abundance of scope to reflect the strategic food and oil security of India from the macroeconomic perspective; the gradual increase in investor and consumer confidence with respect to self-reliance in production and consumption of oil and natural gas resources in the country and the broader social impact of the project, which may be taken up in subsequent research. 


\section{References}

Asian Development Bank (2011), Economic Analysis, National Grid Improvement Project, RRP

IND 44426 and 44917, accessed from http://www2.adb.org/Documents/RRPs/IND/44426/44426-014-ind-ea.pdf

Chaudhuri, Sumana; Vasigh, Bijan; Chaudhuri, Ranjan, (2015), "Estimation of fair rate of return on equity for Delhi International Airport," Journal of Airport Management, Vol. 9 Issue 1, pp. 76 91

Chawla Krishan (1987), Social Cost-Benefit Analysis: An Introduction to Financial and Economic Appraisal of Projects, Mittal Publishers, ISBN 9788170990222

Dinara Millington, Rob McWhinney, Zoey Walden (2014), "Refining Bitumen: Costs, Benefits and Analysis," Study No. 145, Canadian Energy Research Institute (CERI)

Dupuit, A.J., (1844), "On the measurement of the utility of public works," International Economic Papers, Vol. 2, 1952

Evaluation Unit, DG Regional Policy, European Commission (July 2008), Guide to Cost-Benefit Analysis of investment projects: Structural Funds, Cohesion Fund and Instrument for PreAccession, accessed from http://ec.europa.eu/regional policy/sources/docgener/guides/cost/guide2008 en.pdf

Flyvbjerg, B., Bruzelius, N., \& Rothengatter, W. (2003), Megaprojects and risk: an anatomy of ambition, Cambridge: Cambridge University Press

Marshall Goldberg (2013), "Petroleum Refinery Jobs and Economic Development Impact (JEDI) Model User Reference Guide," National Renewable Energy Laboratory (NREL), Subcontract Report NREL/SR-6A20-60657, U.S. Department of Energy Office of Energy Efficiency \& Renewable Energy, Alliance for Sustainable Energy, LLC

Mishan, E.J., \& Quah, E. (2007), Cost-benefit analysis (5th ed). New York: Routeledge 
Munger, M. (2000), Analyzing policy: choices, conflicts and practices, New York: W.W. Norton

Nash, C.A. (1991), The case for high speed rail, Institute of Transport Studies, University of Leeds. Working Paper 323

Ninan, K. N. (2008), Cost-benefit analysis: An introduction, Santa Barbara: Donald Bren School of Environmental Science and Management, University of California

OECD (1969), Manual of industrial project analysis. Volume II. Social cost-benefit analysis, Paris: OECD

United Nations Industrial Development Organization (1972), Guidelines for project evaluation, New York: United Nations

World Bank (1975), Economic analysis of projects, Washington DC: World Bank

World Bank (2004), Monitoring and evaluation: Some tools, methods and approaches, Washington DC: World Bank 


\section{Annex 1: Impact on the Local Economy after the Essar's Refinery}

The Vadinary refinery has 12 core adjoining villages, which have seen large-scale economic development after the setting up of the refinery. The 12 villages are Mithoi, Jhakar, Singach, Vadinar, Bharana, Timbdi, Kajurda, Mota Mandha, Nana Mandha, Kathi Devariya, Sodha Taraghadi and Parodiya.

\section{Status of Housing}

After the establishment of the Vadinar refinery, there has been a large-scale construction of housing units. A total of 925 housing units were constructed after the setting up of the refinery across 12 villages. Prior to the refinery, there were just 93 dwelling units. A total of 9,250 people were involved in the construction of the houses after the establishment of the refinery as against only 930 prior to the establishment of refinery. An amount of Rs. 92.50 crore went as investment in construction of the housing units as against Rs. 6.43 crore prior to the setting up of the refinery.

\section{Graph 1: Status of Housing Units before and after Setting up of the Refinery.}

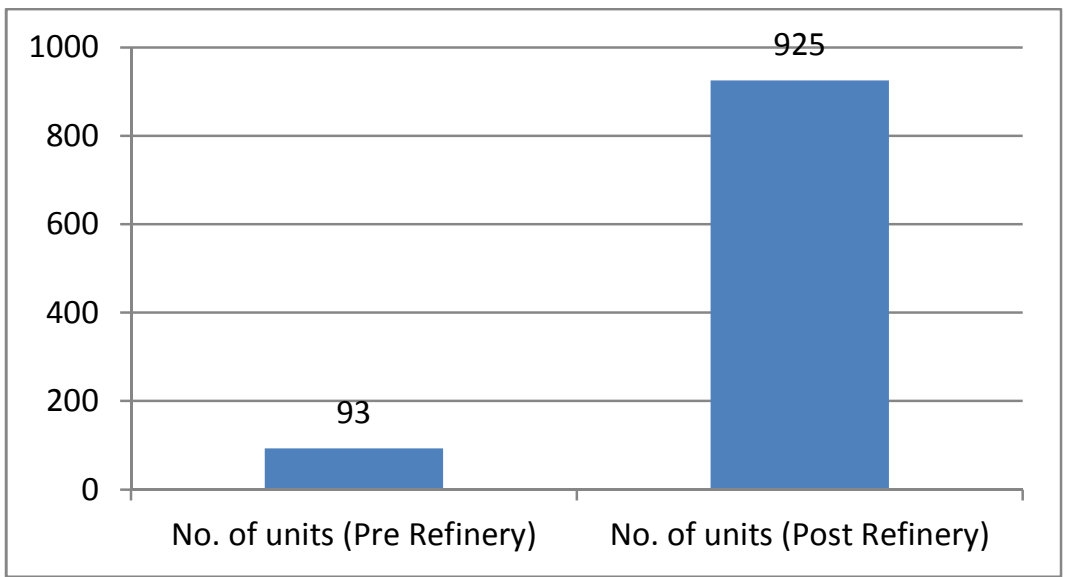


Graph 2: Status of Employment Generated during Construction of Housing Units before and after Setting up of the Refinery.

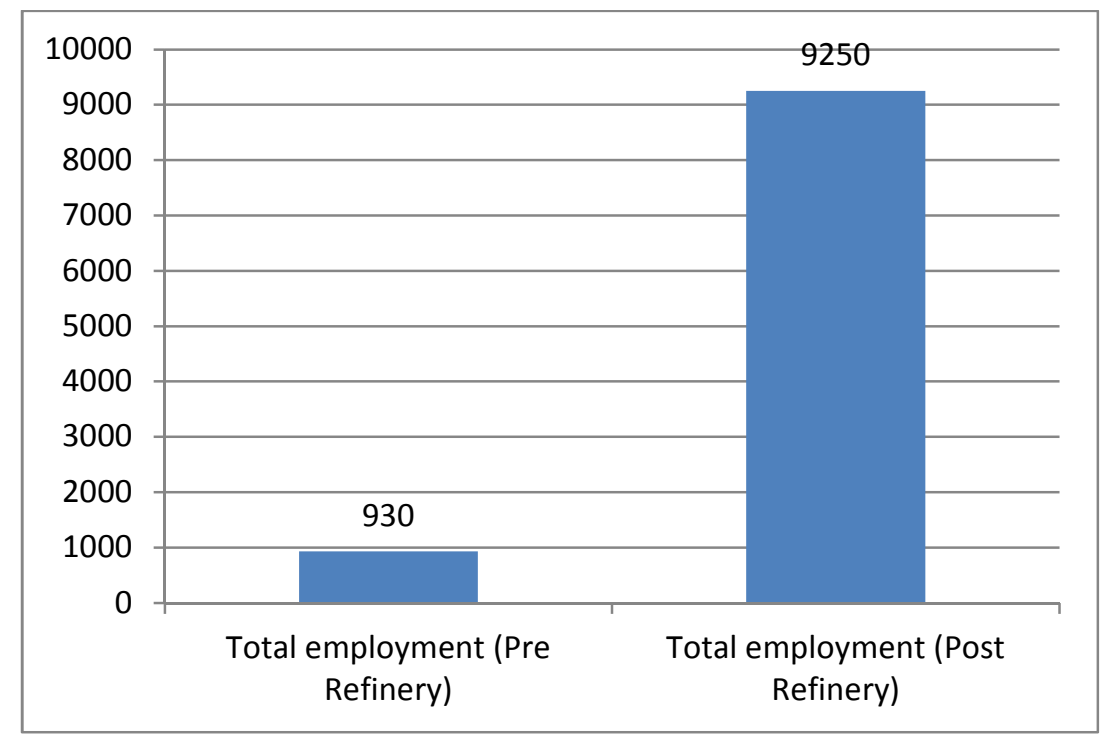

Graph 3: Status of Investments made during the Construction of Housing Units before and after Setting up of the Refinery (Rs. in lakhs)

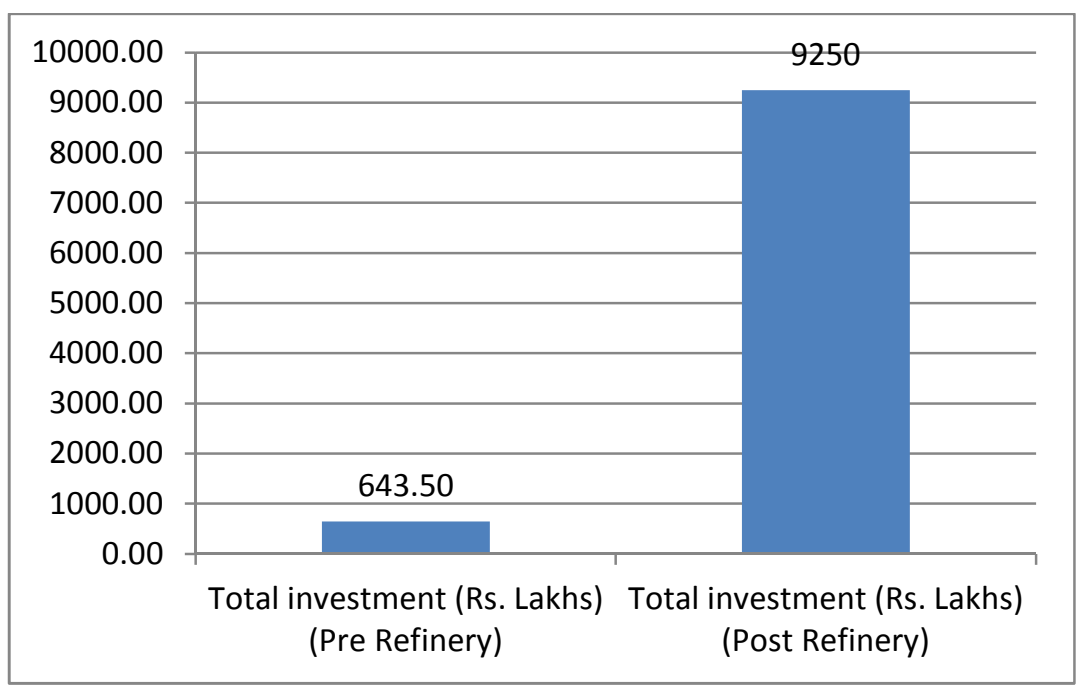

\section{Status of Construction and Engineering Service Providers}

After the setting up of the refinery, the adjoining villages witnessed a spurt in the construction and engineering service providers comprising black smith, bar bending service providers, carpenters, masons, suppliers of construction materials and construction contractors among others. The establishment of the Refinery saw 826 such service providers come up in the villages and 2,501 people earning their livelihood out of this activity. A total of Rs. 1.61 crore was invested by these service providers. Prior to the refinery, there were only 103 such providers and 248 people earned their livelihood from this activity. Only Rs. 15 lakhs were invested by these service providers during this duration. 
Graph 4: Status of Construction and Engineering Service Providers before and after Setting up of the Refinery.

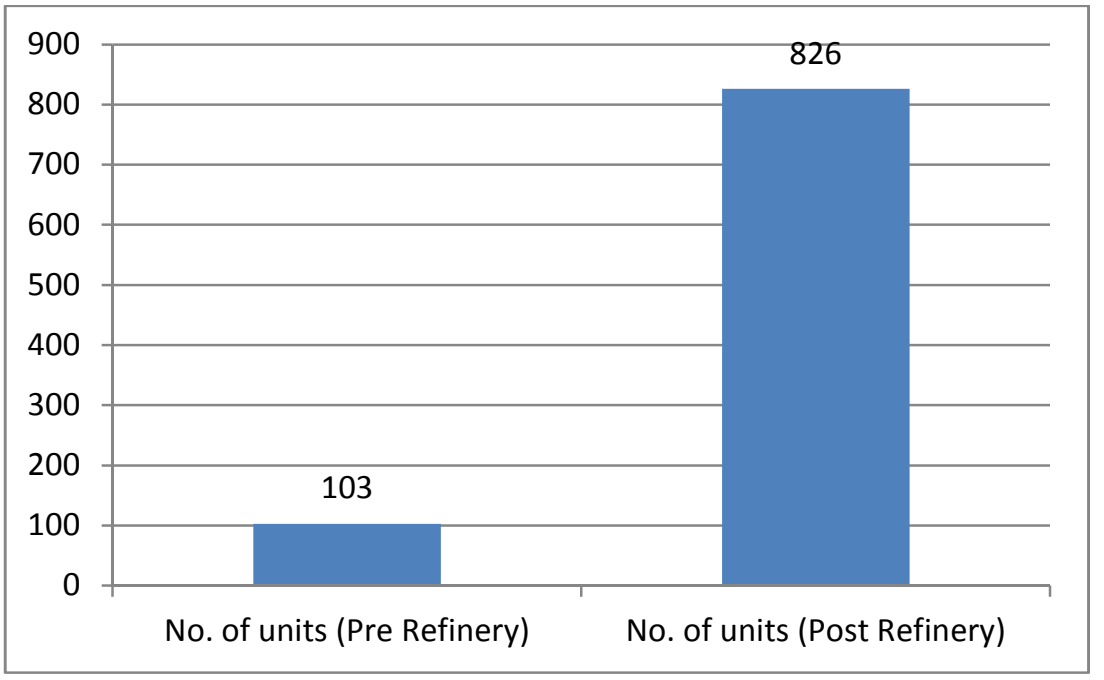

Graph 5: Status of Employment Generated by Construction and Engineering Service Providers before and after Setting up of the Refinery.

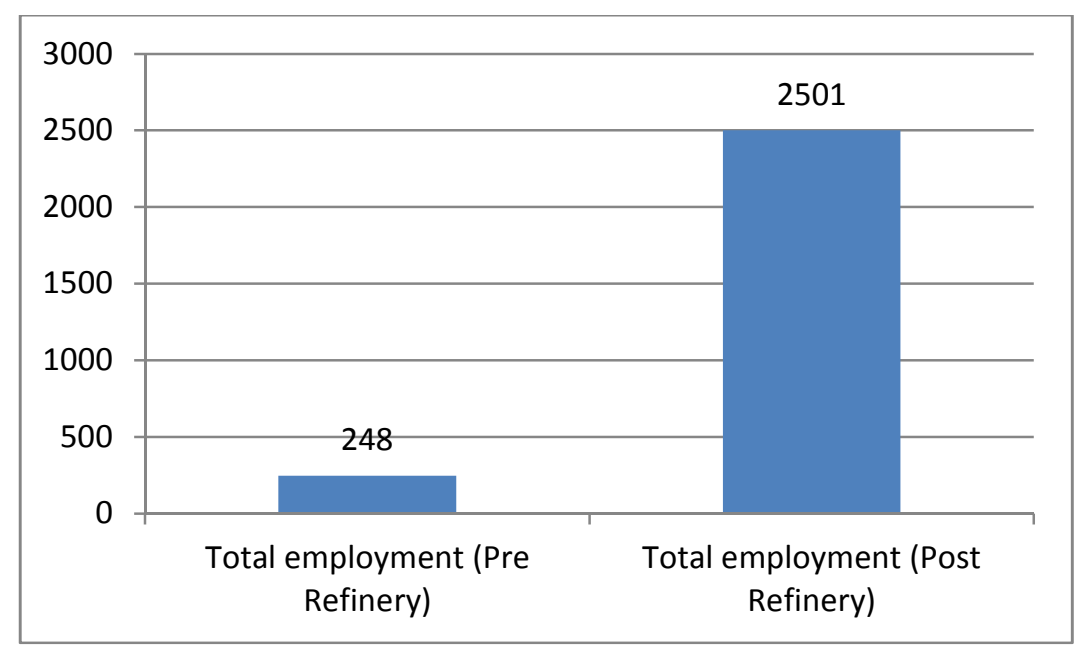


Graph 6: Status of Investment made by Construction and Engineering Service Providers before and after Setting up of the Refinery. (Rs. in lakhs)

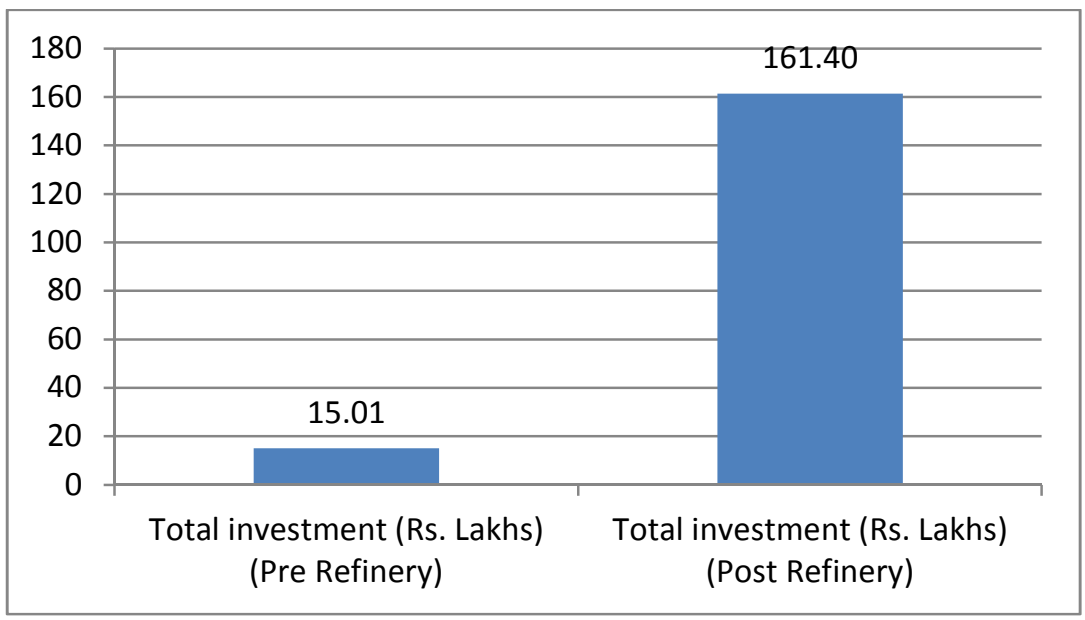

\section{Status of Healthcare and related Services}

After the establishment of the Refinery, 12 clinics and medical shops were set up as against only 4 such clinics and medical shops. 24 people were involved in providing this service after the Refinery and an investment of Rs. 17.2 lakhs was made in setting up these clinics and medical shops. Prior to the Refinery, only 8 people were involved in providing this service and only Rs. 1.95 lakhs were invested in setting up the clinics and medical shops.

Graph 7: Status of Health and related Services before and after Setting up of the Refinery.

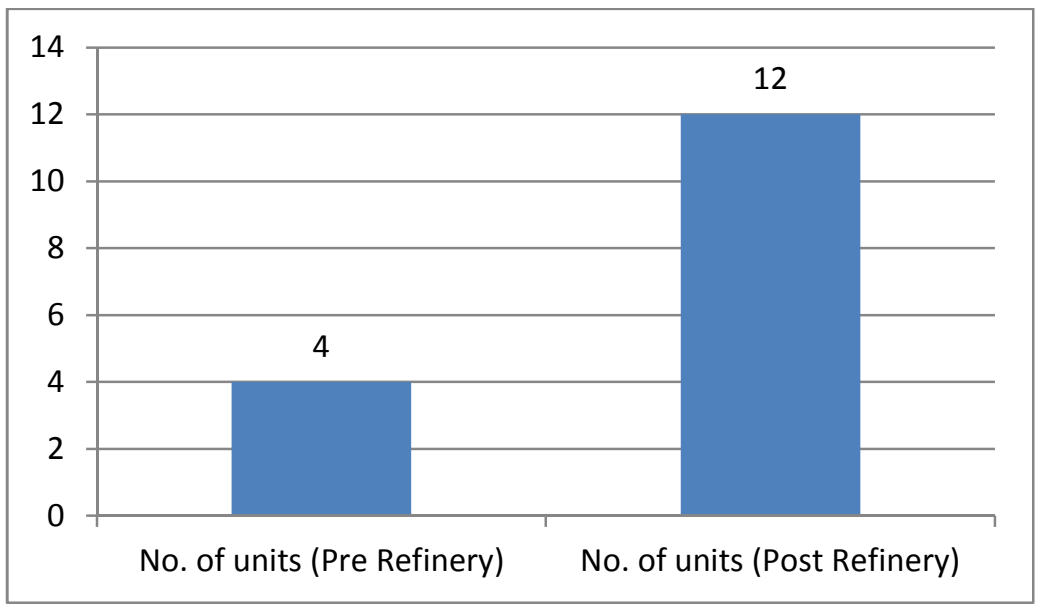


Graph 8: Status of Employment Generated by Health and related Services before and after Setting up of the Refinery.

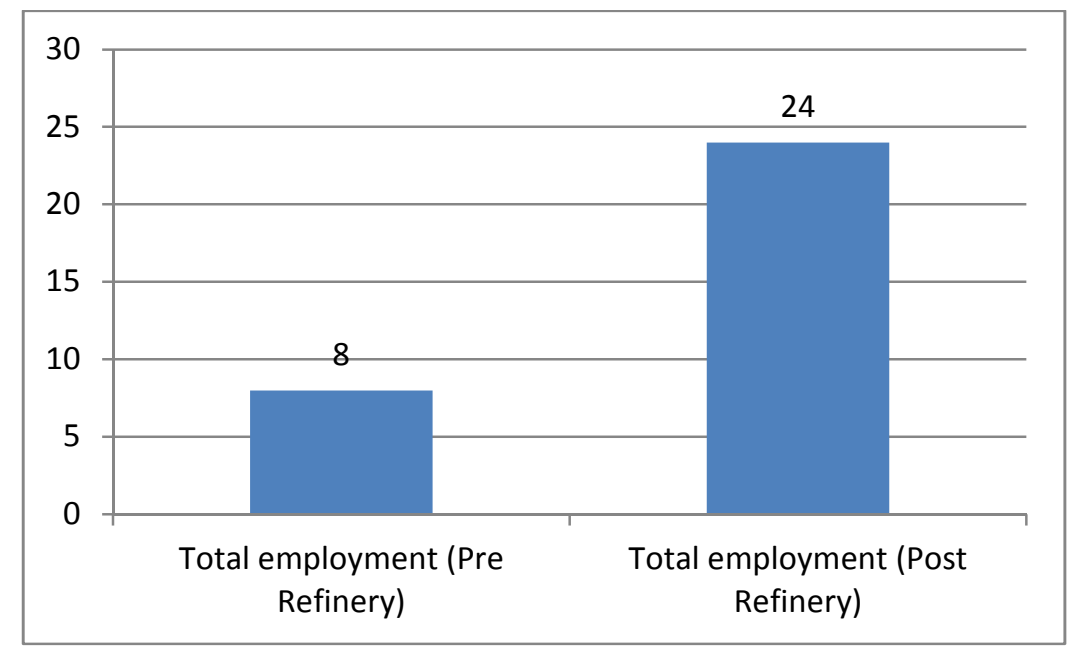

Graph 9: Status of Investment made by Health and related Services before and after Setting up of the Refinery (Rs. in lakhs)

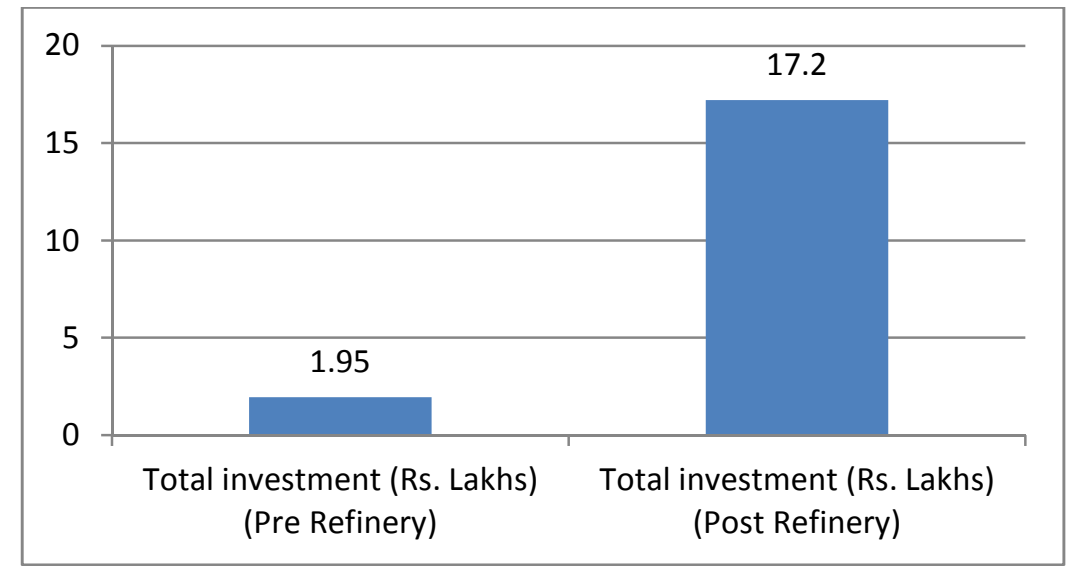

\section{Status of Education}

The establishment of the Refinery saw the educational service providers improve in the adjoining villages. After the Refinery came up, 44 schools, stationery shops and tutorial centers were set up providing employment to 146 people and an investment of Rs. 1.77 crores was made on the same. Before the Refinery, there were only 13 schools, stationery shops and tutorial centers with 27 people involved in it. Only Rs. 14 lakhs were invested in this infrastructure before the setting up of the Refinery. 
Graph 10: Status of Educational Service Providers before and after Setting up of the Refinery.

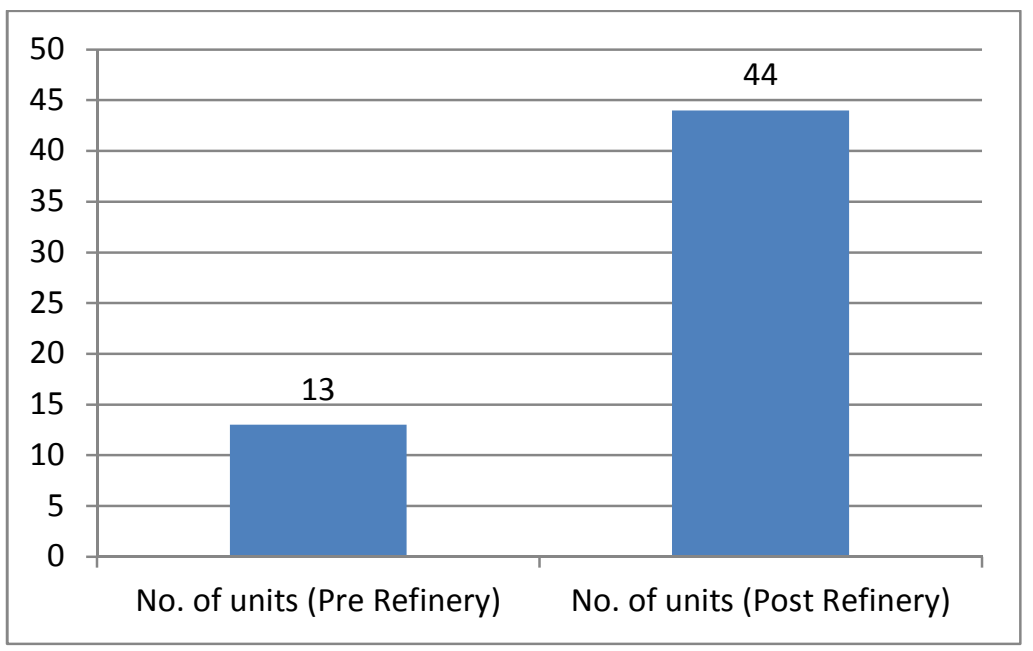

Graph 11: Status of Employment Generated through Educational Services Providers before and after Setting up of the Refinery.

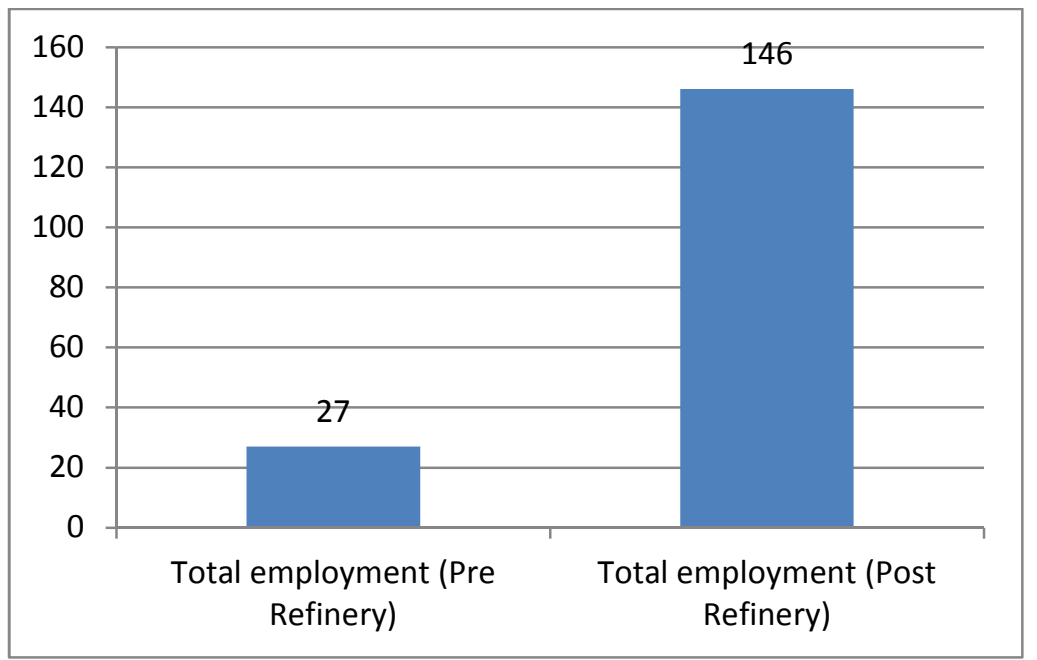


Graph 12: Status of Investment made by Educational Services Providers before and after Setting up of the Refinery (Rs. in lakhs)

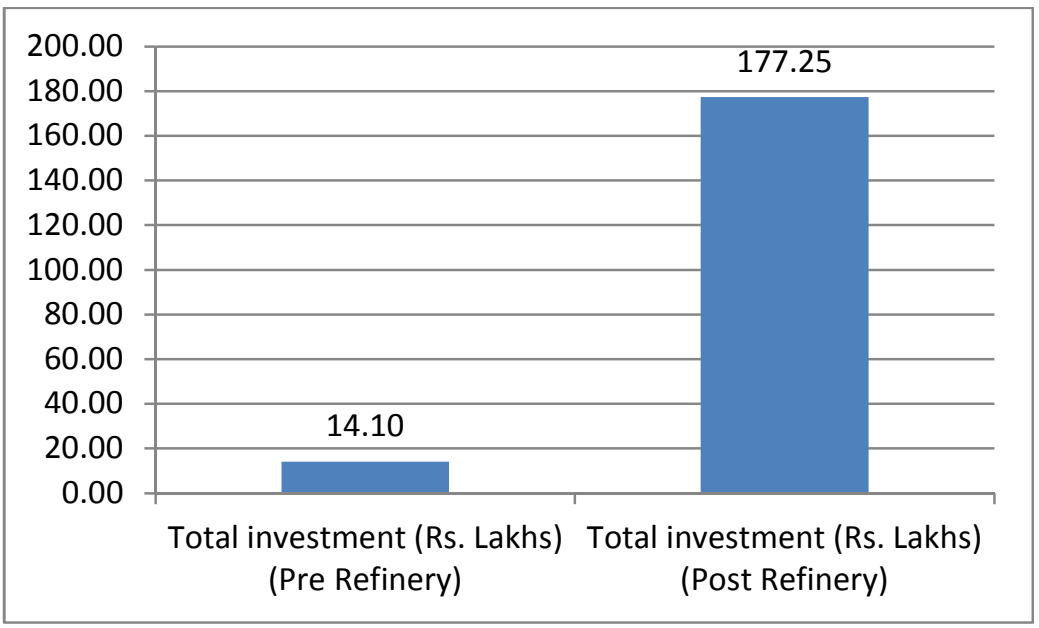

\section{Status of Local Businesses and Service Providers}

The setting up of Refinery saw 1,945 local businesses and service providers establish their presence in the 12 villages, which included petty shops, courier service, electricians, decorators, tailors, maids etc. and they provided employment to 2,876 people. A total investment of Rs. 6.70 crore was made by these service providers. Prior to the refinery, only 265 such local businesses and service providers existed, which provided employment to 420 people. Only Rs. 16.73 lakhs were invested on these services.

Graph 13: Status of Local Businesses and Service Providers before and after Setting up of

\section{Refinery}

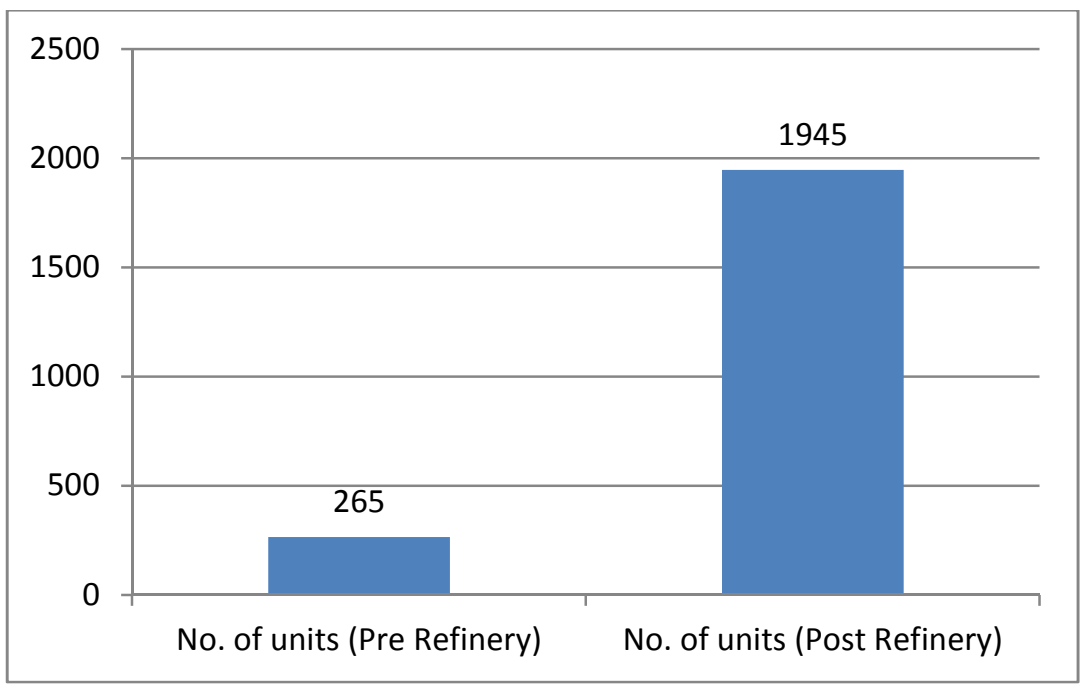


Graph 14: Status of Employment Generated by Local Businesses and Service Providers before and after Setting up of Refinery

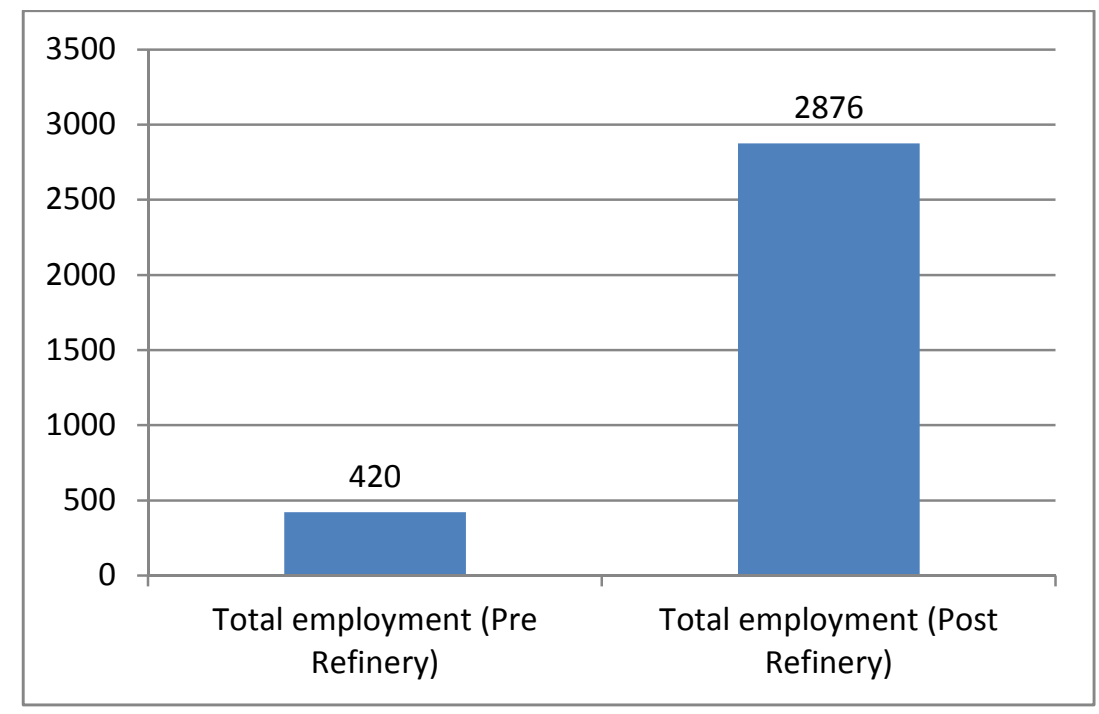

Graph 15: Status of Investment made by Local Businesses and Service Providers before and after Setting up of Refinery (Rs. in lakhs)

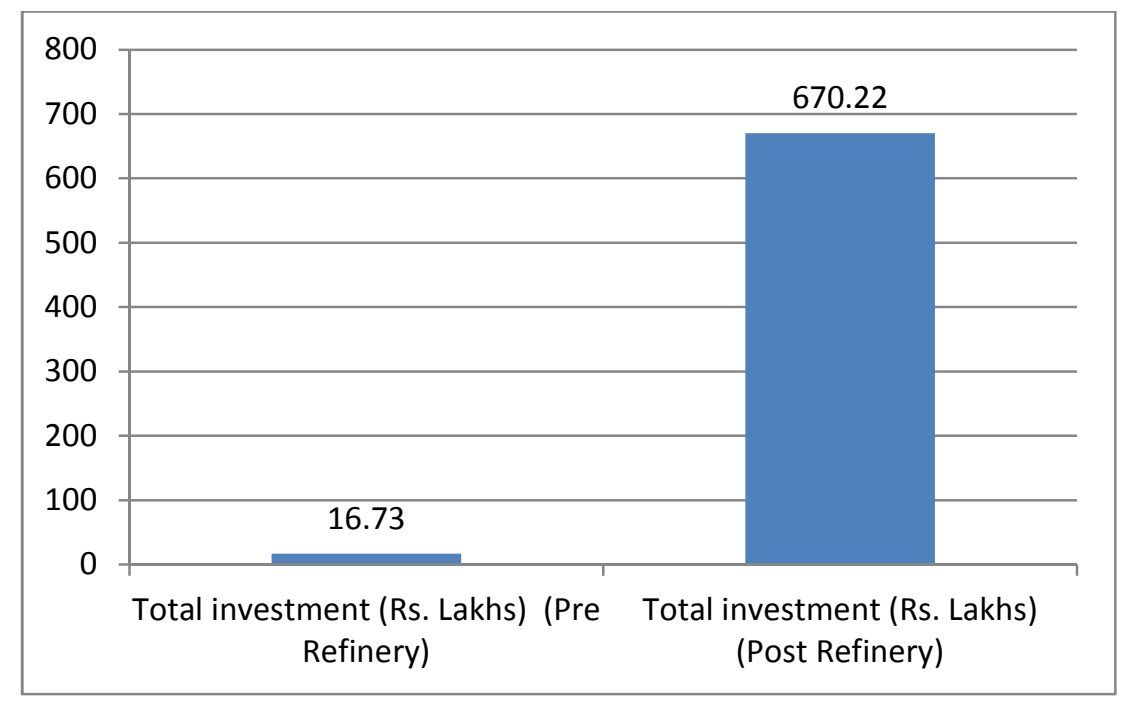

\section{Status of Public Service Infrastructure}

The establishment of the Refinery saw 235 public service infrastructure facilities being set up including banks, convention hall, post office, ration shops and so on at an investment of nearly Rs. 4 crore and providing employment to 220 people. Prior to the Refinery, there were only 34 such public service infrastructure facilities created at an investment of Rs. 24 lakhs and employing 99 people. 
Graph16: Status of Public Service Infrastructure before and after Setting up of Refinery

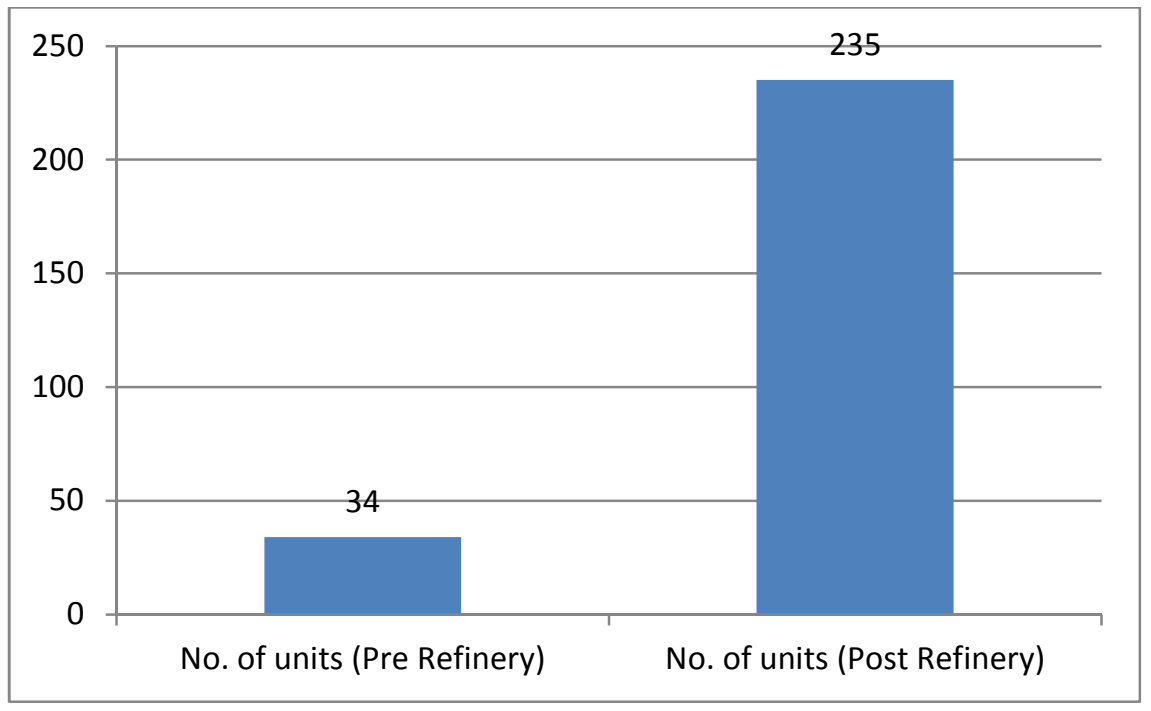

Graph17: Status of Employment Generated through Public Service Infrastructure before and after Setting up of Refinery

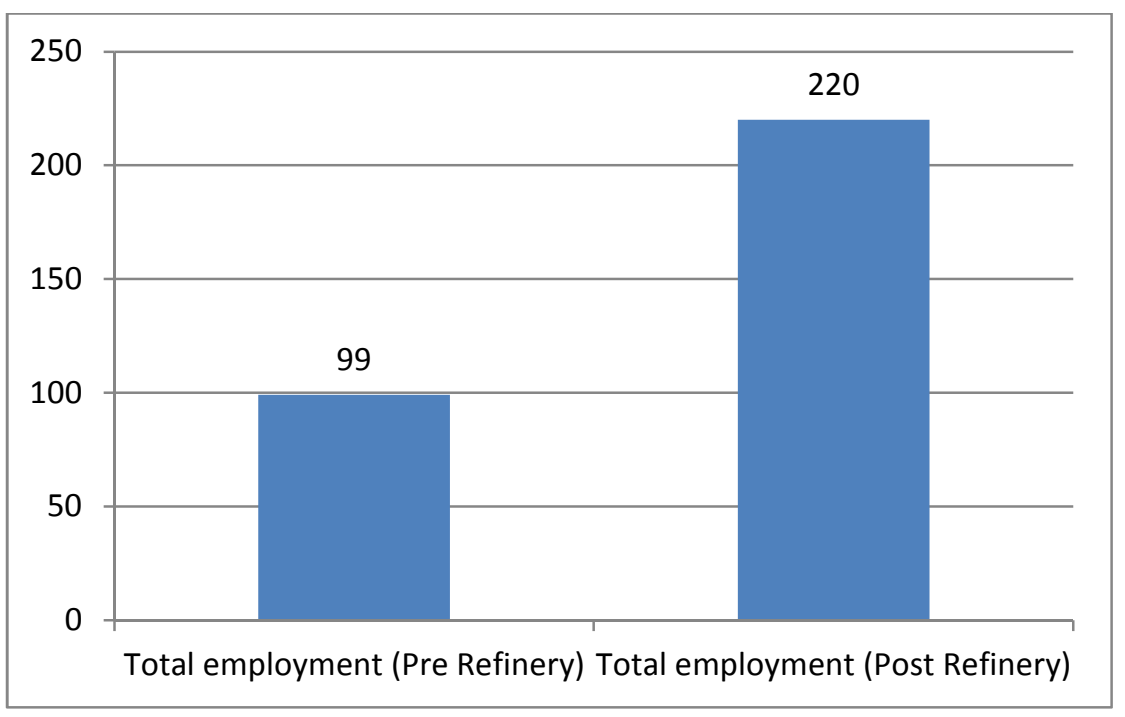


Graph18: Status of Investment made by Public Service Infrastructure before and after Setting up of Refinery (Rs. in lakhs)

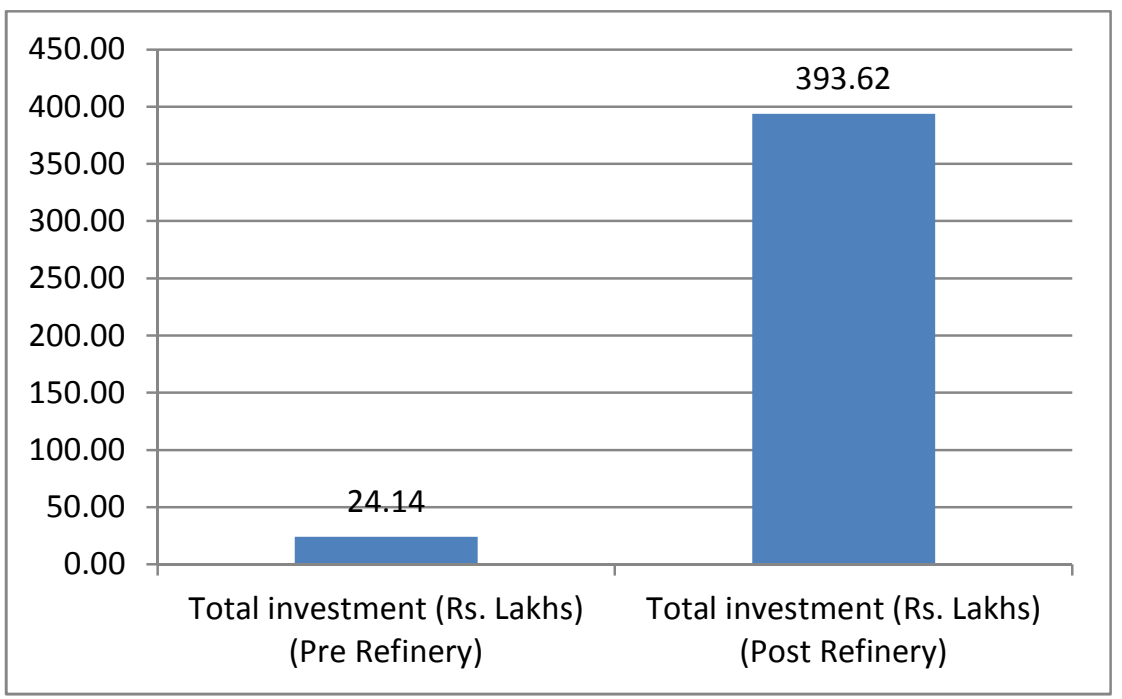

\section{Status of Other Infrastructure}

The establishment of Refinery also saw a rise in other infrastructure including vehicles, JCBs and trailors. The villages saw 2,085 such vehicles, JCBs and trailors purchased at an investment of Rs. 31.35 crore providing employment to 90 people. Before the Refinery, there only 215 such infrastructure facilities purchased at an investment of Rs. 1.11 crore and employing only 6 people.

Graph 19: Status of Other Infrastructure before and after Setting up of Refinery

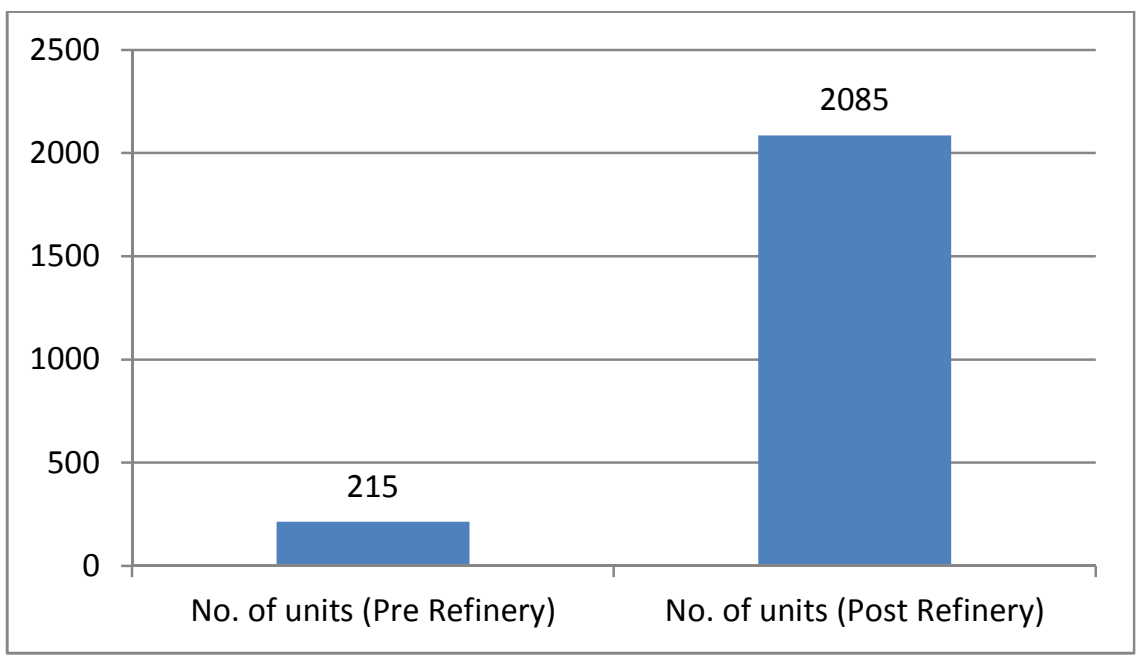


Graph 20: Status of Employment Generated through Other Infrastructure before and after Setting up of Refinery

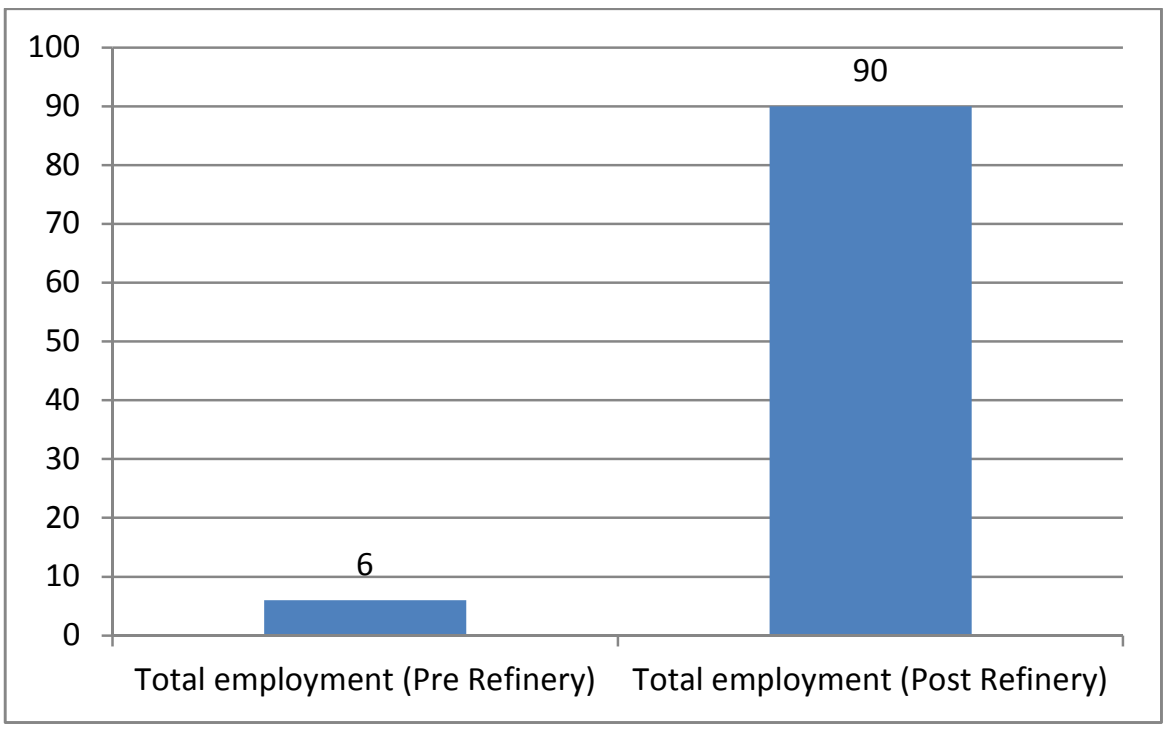

Graph 21: Status of Investment done through Other Infrastructure before and after Setting up of Refinery (Rs. in lakhs)

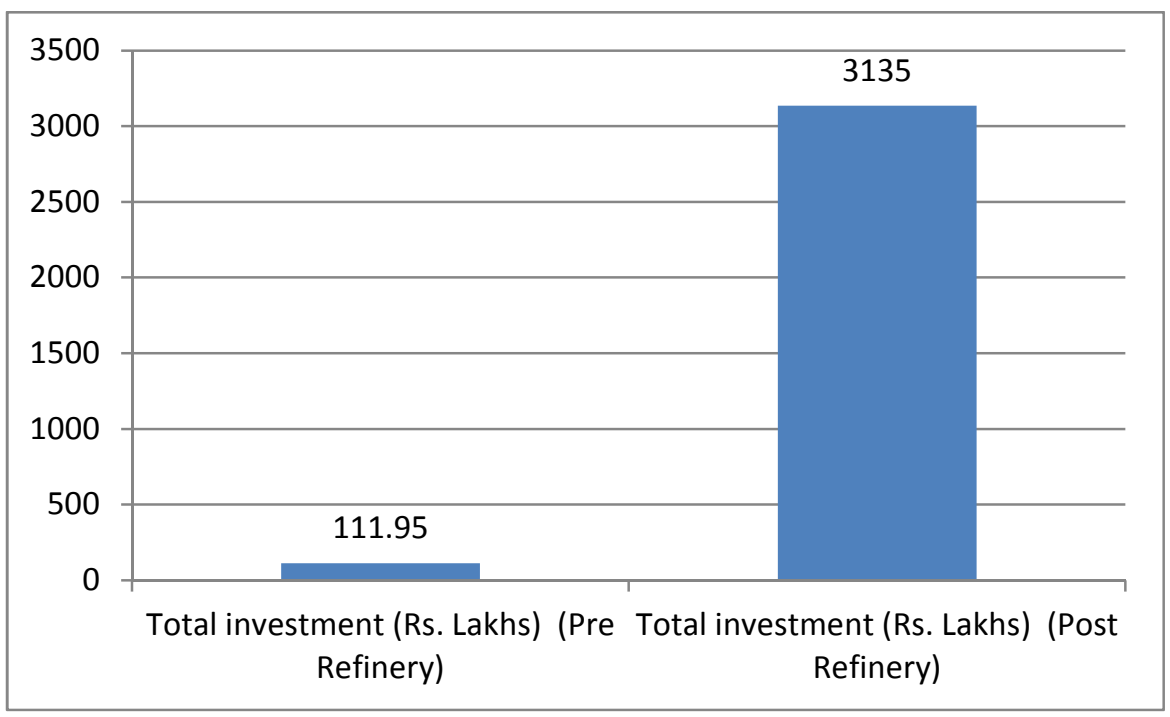




\section{Tables}

Table 1: Status of Housing Units before and after Setting up of the Refinery

\begin{tabular}{|c|c|c|c|c|c|}
\hline $\begin{array}{l}\text { No. of } \\
\text { units } \\
\text { (Pre } \\
\text { Refinery) }\end{array}$ & $\begin{array}{l}\text { No. of } \\
\text { units } \\
\text { (Post } \\
\text { Refinery) }\end{array}$ & $\begin{array}{l}\text { Total } \\
\text { investment } \\
\text { (Rs. } \\
\text { Lakhs) } \\
\text { (Pre } \\
\text { Refinery) }\end{array}$ & $\begin{array}{l}\text { Total } \\
\text { investment } \\
\text { (Rs. } \\
\text { Lakhs) } \\
\text { (Post } \\
\text { Refinery) }\end{array}$ & $\begin{array}{l}\text { Total } \\
\text { employment } \\
\text { (Pre } \\
\text { Refinery) }\end{array}$ & $\begin{array}{l}\text { Total } \\
\text { employment } \\
\text { (Post } \\
\text { Refinery) }\end{array}$ \\
\hline 93 & 925 & 643.50 & 9250 & 930 & 9250 \\
\hline
\end{tabular}

Table 2: Status of Construction and Engineering Service Providers before and after Setting up of the Refinery.

\begin{tabular}{|c|c|c|c|c|c|}
\hline $\begin{array}{l}\text { No. of } \\
\text { units } \\
\text { (Pre } \\
\text { Refinery) }\end{array}$ & $\begin{array}{l}\text { No. of } \\
\text { units } \\
\text { (Post } \\
\text { Refinery) }\end{array}$ & $\begin{array}{l}\text { Total } \\
\text { investment } \\
\text { (Rs. } \\
\text { Lakhs) } \\
\text { (Pre } \\
\text { Refinery) }\end{array}$ & $\begin{array}{l}\text { Total } \\
\text { investment } \\
\text { (Rs. } \\
\text { Lakhs) } \\
\text { (Post } \\
\text { Refinery) }\end{array}$ & $\begin{array}{l}\text { Total } \\
\text { employment } \\
\text { (Pre } \\
\text { Refinery) }\end{array}$ & $\begin{array}{l}\text { Total } \\
\text { employment } \\
\text { (Post } \\
\text { Refinery) }\end{array}$ \\
\hline 103 & 826 & 15.01 & 161.40 & 248 & 2501 \\
\hline
\end{tabular}

Table 3: Status of Health and related Services before and after Setting up of the Refinery.

\begin{tabular}{|c|c|c|c|c|c|}
\hline $\begin{array}{l}\text { No. of } \\
\text { units } \\
\text { (Pre } \\
\text { Refinery) }\end{array}$ & $\begin{array}{l}\text { No. of } \\
\text { units } \\
\text { (Post } \\
\text { Refinery) }\end{array}$ & $\begin{array}{l}\text { Total } \\
\text { investment } \\
\text { (Rs. } \\
\text { Lakhs) } \\
\text { (Pre } \\
\text { Refinery) }\end{array}$ & $\begin{array}{l}\text { Total } \\
\text { investment } \\
\text { (Rs. } \\
\text { Lakhs) } \\
\text { (Post } \\
\text { Refinery) }\end{array}$ & $\begin{array}{l}\text { Total } \\
\text { employment } \\
\text { (Pre } \\
\text { Refinery) }\end{array}$ & $\begin{array}{l}\text { Total } \\
\text { employment } \\
\text { (Post } \\
\text { Refinery) }\end{array}$ \\
\hline 4 & 12 & 1.95 & 17.2 & 8 & 24 \\
\hline
\end{tabular}

Table 4: Status of Educational Service Providers before and after Setting up of the Refinery. 


\begin{tabular}{|c|c|c|c|c|c|}
\hline $\begin{array}{l}\text { No. of } \\
\text { units } \\
\text { (Pre } \\
\text { Refinery) }\end{array}$ & $\begin{array}{l}\text { No. of } \\
\text { units } \\
\text { (Post } \\
\text { Refinery) }\end{array}$ & $\begin{array}{l}\text { Total } \\
\text { investment } \\
\text { (Rs. } \\
\text { Lakhs) } \\
\text { (Pre } \\
\text { Refinery) }\end{array}$ & $\begin{array}{l}\text { Total } \\
\text { investment } \\
\text { (Rs. } \\
\text { Lakhs) } \\
\text { (Post } \\
\text { Refinery) }\end{array}$ & $\begin{array}{l}\text { Total } \\
\text { employment } \\
\text { (Pre } \\
\text { Refinery) }\end{array}$ & $\begin{array}{l}\text { Total } \\
\text { employment } \\
\text { (Post } \\
\text { Refinery) }\end{array}$ \\
\hline 13 & 44 & 14.10 & 177.25 & 27 & 146 \\
\hline
\end{tabular}

Table 5: Status of Local Businesses and Service Providers before and after Setting up of Refinery

\begin{tabular}{|c|c|c|c|c|c|}
\hline $\begin{array}{l}\text { No. of } \\
\text { units } \\
\text { (Pre } \\
\text { Refinery) }\end{array}$ & $\begin{array}{l}\text { No. of } \\
\text { units } \\
\text { (Post } \\
\text { Refinery) }\end{array}$ & $\begin{array}{l}\text { Total } \\
\text { investment } \\
\text { (Rs. } \\
\text { Lakhs) } \\
\text { (Pre } \\
\text { Refinery) }\end{array}$ & $\begin{array}{l}\text { Total } \\
\text { investment } \\
\text { (Rs. } \\
\text { Lakhs) } \\
\text { (Post } \\
\text { Refinery) }\end{array}$ & $\begin{array}{l}\text { Total } \\
\text { employment } \\
\text { (Pre } \\
\text { Refinery) }\end{array}$ & $\begin{array}{l}\text { Total } \\
\text { employment } \\
\text { (Post } \\
\text { Refinery) }\end{array}$ \\
\hline 265 & 1945 & 16.73 & 670.22 & 420 & 2876 \\
\hline
\end{tabular}

Table 6: Status of Public Service Infrastructure before and after Setting up of Refinery

\begin{tabular}{|c|c|c|c|c|c|}
\hline $\begin{array}{l}\text { No. of } \\
\text { units } \\
\text { (Pre } \\
\text { Refinery) }\end{array}$ & $\begin{array}{l}\text { No. of } \\
\text { units } \\
\text { (Post } \\
\text { Refinery) }\end{array}$ & $\begin{array}{l}\text { Total } \\
\text { investment } \\
\text { (Rs. } \\
\text { Lakhs) } \\
\text { (Pre } \\
\text { Refinery) }\end{array}$ & $\begin{array}{l}\text { Total } \\
\text { investment } \\
\text { (Rs. } \\
\text { Lakhs) } \\
\text { (Post } \\
\text { Refinery) }\end{array}$ & $\begin{array}{l}\text { Total } \\
\text { employment } \\
\text { (Pre } \\
\text { Refinery) }\end{array}$ & $\begin{array}{l}\text { Total } \\
\text { employment } \\
\text { (Post } \\
\text { Refinery) }\end{array}$ \\
\hline 34 & 235 & 24.14 & 393.62 & 99 & 220 \\
\hline
\end{tabular}


Table 7: Status of Other Infrastructure before and after Setting up of Refinery

\begin{tabular}{|c|c|c|c|c|c|}
\hline $\begin{array}{l}\text { No. of } \\
\text { units } \\
\text { (Pre } \\
\text { Refinery) }\end{array}$ & $\begin{array}{l}\text { No. of } \\
\text { units } \\
\text { (Post } \\
\text { Refinery) }\end{array}$ & $\begin{array}{l}\text { Total } \\
\text { investment } \\
\text { (Rs. } \\
\text { Lakhs) } \\
\text { (Pre } \\
\text { Refinery) }\end{array}$ & $\begin{array}{l}\text { Total } \\
\text { investment } \\
\text { (Rs. } \\
\text { Lakhs) } \\
\text { (Post } \\
\text { Refinery) }\end{array}$ & $\begin{array}{l}\text { Total } \\
\text { employment } \\
\text { (Pre } \\
\text { Refinery) }\end{array}$ & $\begin{array}{l}\text { Total } \\
\text { employment } \\
\text { (Post } \\
\text { Refinery) }\end{array}$ \\
\hline 215 & 2085 & 111.95 & 3135 & 6 & 90 \\
\hline
\end{tabular}

Summary of the Employment, Salaries, Businesses \& Service Providers, Investment and

Revenues associated with Local Economy as a result of Establishment of the Refinery

\begin{tabular}{|c|c|}
\hline Total No. of Employees & 15107 \\
\hline $\begin{array}{l}\text { Total Investment made Post Refinery by Local Businesses and Service } \\
\text { Providers (Rs. in Lakhs) }\end{array}$ & 13804.69 \\
\hline Total Enterprises and service providers & 6072 \\
\hline $\begin{array}{l}\text { Total Income of Employee associated with Local Businesses and } \\
\text { Service Providers (Rs. in Lakhs) }\end{array}$ & 77347.84 \\
\hline $\begin{array}{l}\text { Total Revenue Earned by Local Businesses and Service Providers (Rs. } \\
\text { in Lakhs) }\end{array}$ & 255247.872 \\
\hline \multicolumn{2}{|c|}{$\begin{array}{l}\text { Note: } 1 \text {. It is assumed that } 200 \text { employment days were generated over the period of } 20 \text { years and } \\
\text { an average daily wage of Rs. } 128 \text { is considered based on the average of annual wages of semi- } \\
\text { skilled workers over the years as notified by the Labour and Welfare Department, Government of } \\
\text { Gujarat }\end{array}$} \\
\hline $\begin{array}{l}\text { 2. Regarding revenue, the general assumption of salaries comprisin } \\
\text { revenues is followed although there is no blanket standard available. H } \\
\text { percent more than the salaried paid. However, if there is a more accept } \\
\text { be followed in this case. }\end{array}$ & $\begin{array}{l}\text { g } 30 \text { percent of the total } \\
\text { ence, the total revenue is } 70 \\
\text { ed standard available, it can }\end{array}$ \\
\hline
\end{tabular}

